Article

\title{
Exercising under COVID-2x: Conceptualizing Future Green Spaces in Australia's Neighborhoods
}

\author{
Dirk H. R. Spennemann
}

Citation: Spennemann, D.H.R. Exercising under COVID-2x: Conceptualizing Future Green Spaces in Australia's Neighborhoods. Urban Sci. 2021, 5, 93. https://doi.org/ 10.3390/urbansci5040093

Academic Editor: Francesco Ferrin

Received: 8 October 2021

Accepted: 5 December 2021

Published: 13 December 2021

Publisher's Note: MDPI stays neutral with regard to jurisdictional claims in published maps and institutional affiliations.

Copyright: (c) 2021 by the author Licensee MDPI, Basel, Switzerland. This article is an open access article distributed under the terms and conditions of the Creative Commons Attribution (CC BY) license (https:// creativecommons.org/licenses/by/ $4.0 /)$
Institute for Land, Water and Society, Charles Sturt University, P.O. Box 789, Albury, NSW 2640, Australia; dspennemann@csu.edu.au

\begin{abstract}
The COVID-19 pandemic has proven to be a social and economic disruptor on a global scale, severely curtailing people's ability to travel and engage in many recreation activities. Periodic lockdown and stay-at-home orders have exacerbated the situation. In this social climate, urban green spaces have attained a high significance for the maintenance of the physical and mental health of the population. Given the presence of similar coronaviruses in animal populations, it can be predicted that future epidemics and even pandemics will occur. Urban planning needs to incorporate the lessons learnt during COVID-19 in order to future-proof our communities. This paper reviews the role that urban green spaces played during the COVID-19 pandemic. Based on these observations, the paper discusses a range of options for the provision of pandemic-sensitive spaces for physical exercise and mental recreation. Design concepts for long-term planning adjustments as well as for future ad-hoc solutions are provided. These include the provision of social distancing 'pods' embedded in design and landscaping of permanent parks, the design of ad-hoc, socially distanced 'parklets' on a quietened street and a rethink of the design of curb-to-boundary setbacks (nature strip) in residential streets.
\end{abstract}

Keywords: pandemics; epidemiology; urban planning; COVID-19; parks; recreation; exercise green spaces

\section{Introduction}

During the first quarter of 2020, COVID-19 rapidly emerged as a truly global pandemic, affecting all but a handful of countries [1]. By mid-2021, most countries had experienced a second and some even a third wave of infections [2]. To suppress or at least slow down the rate of COVID-19 infections and to ensure that their public health system was not overwhelmed by cases requiring hospitalization, governments at all levels have engaged in public health measures that run the gamut from social distancing rules to stay-at-home orders. Due to its cross-sectorial impact and global scale, the COVID-19 pandemic has become the single largest social, cultural and economic disruptor since the 'Spanish flu' pandemic of 1918-19 [3]. At the time of final submission (on 4 October 2021), 249.5 million people had been infected on all continents with a global death toll of 5.0 million [4].

The severe acute respiratory syndrome coronavirus 2 (SARS-CoV-2), which causes COVID-19 [1], is the latest in a line of zoonotic coronavirus that have affected human populations since the start of the twenty-first century: SARS-CoV (2004), MERS-CoV (2012), SADS-CoV (2016) and now SARS-CoV-2. Zoonotic coronaviruses similar to SARS-CoV-2 have been detected in various host species [5] and some of these are almost certain to emerge as a future threat to humans [6]. From an epidemiological point of view it can be posited with a high degree of certainty that COVID-19 will not be the last pandemic [7].

As the world is gradually moving towards a post-pandemic reality with increasing rates of vaccination against COVID-19, attention is shifting to the nature of the post-COVID world. Rather than assuming 'business as usual,' consideration has been given to the future manifestations of living [8], working [9], commuting [10], studying [11], recreation [12], and tourism [13], as well as urban design [14,15], and the future of public spaces [16]. 
This paper considers how the events that unfolded during the COVID-19 pandemic inform the design considerations for the future of urban green spaces. While the paper makes specific reference to the situation in Australia, it has applicability on a wider scale.

\section{The Effects of Lockdown in Communities in Australia and Beyond}

To slow down the progress of COVID-19 and then to suppress or eliminate the spread of SARS-CoV-2, governments enforced public health measures of various duration, that have involved, inter alia, limiting international passenger arrivals to repatriation flights, imposing restrictions on domestic travel (between states or between local government areas), the temporary closure of businesses deemed non-essential (e.g., hair dressers, clothing shops, luxury goods), and enforcing social distancing rules by capping numbers attending public venues. In addition, human movement could be restricted during periods of 'lockdown' by issuing stay-at-home orders $[17,18]$. National and state/provincial governments enforced different levels of lockdowns [19], ranging from restricting people's movements to essential services (accessing health care, buying food, getting COVID tested/vaccinated and limited daily exercise, e.g., Australia) [20] to being allowed to leave the house every second day and then only for food and health care (e.g., Panama) [21] with some sections of society not being allowed to leave the house at all (e.g., youth under 20 in Turkey) [22]. Across the globe, major sporting and cultural events were cancelled or moved to virtual, on-line venues. By and large, people resumed their prior pattern of daily activity once the lockdown regimes were eased, despite the fact that in various parts of the world the pandemic remained uncontrolled with emergent new strains of the virus leading to second, third and fourth waves.

Australia closed its borders for international recreational and business travel in March 2020 [17], while its internal state borders were closed in various forms and combinations from late March, restricting travel both into and within Australia [23]. The primary direct effects of the stay-at-home orders were the closure of childcare centers, schools, colleges, and universities, and the closure of all 'non-essential' workplaces, but excluding emergency services, primary health care, utilities, and the food chain, with restaurants allowed to offer take-away service only. Social events such as religious services and weddings were prohibited, and funerals were restricted to the bare minimum, usually ten persons including the funeral director and clergy [24]. This was coupled with a general prohibition of all "non-essential" population movement [24]. In the Australian setting, permissible reasons to leave the home were to purchase food, to obtain essential medical services, to get a COVID-test and to go for (limited) outdoor exercise [24-27]. It was mandatory to wear face-masks and to maintain social distancing while engaged in permissible activities outside the home, with the exception of outdoor exercise where masks were not required provided that social distancing was maintained [27-30].

\section{Impact of Stay-at-Home Orders on People's Ability to Exercise and Recreate}

Traditionally, public open spaces such as national parks, in particular in peri-urban areas, are used for a range of outdoor recreation activities, with urban green spaces used for exercise, mental regeneration and socializing. With the national border closures and the effective termination of international travel, domestic recreational tourism and demand for 'micro-adventure' opportunities increased [31], leading to an increased visitation of national parks [32-34]. As the required social distancing could not be maintained in the face of increased visitation, many national parks closed in Australia at the onset of COVID-19 [17].

During the lockdown period many people experienced a higher level of psychological stressors, both in frequency and intensity. Social isolation, coupled with potentially harmful interpersonal and environmental stimuli, on occasion resulted in deteriorating family relationships, including abuse and domestic violence [35,36]. Sections of the community, such as older people, people with poor mental health, people with disability, people with non-communicable diseases, people who were homeless, people living on their own, and people with reduced communication and limited social networks beyond their work set- 
tings, were disproportionately at risk [35,37], with the pandemic both exacerbating existing mental health conditions [37-40] and creating and intensifying inequalities [36,40-43].

Repeated lockdowns, coupled with subsequent limitations on participant ratios due to the imposition of social distancing rules, led to a downturn of the outdoor recreation industry [12]. As gymnasiums and fitness centers were also affected by the lockdown rules [44], personal physical exercise either declined, was replaced by classes delivered via social media, or shifted to outdoor areas, often with capped numbers [45-48].

\section{Utilization of Urban Green Spaces during the COVID-19 Pandemic}

Pre-pandemic studies have shown that urban green spaces have well-established benefits for both the physical and the mental health of the population [49-53]. Unsurprisingly, then, the perception of urban green spaces as important for mental and physical health increased during the pandemic [54-56]. Indeed, the repeated lockdowns and movement restrictions led to an increased use of the local outdoor environment, in particular urban and peri-urban green spaces [57-60]. An increased use of urban green spaces has been observed during the COVID-19 pandemic throughout Europe, including Belgium [55], Croatia [61], England [62,63], Germany [64], Italy [61,65,66], Lithuania [61], Norway [57], Finland [67], Russia [68], Slovenia [61], Spain [61], and in other parts of the globe, such as China [56,69,70], Singapore [69], South Korea [69], Japan [69,71], Israel [61], Mexico [72], the U.S.A. [42], and Australia [68]. While the extent of this increased use differed, this trend was particularly prevalent in large agglomerations such as Hong Kong, Singapore, Tokyo, and Seoul [69].

As the overall use increased, irrespective of the size of the parks, the relative accessibility became the governing factor [63,72]. Consequently, in some areas, local authorities closed the local parks, in particular the smaller parks, due to perceived or actual crowding when these parks served as proxy social venues [54,66,73-75]. This fear was not unfounded, with some studies noting that highly connected green spaces, which offer a high choice of activities, were associated with an increased risk of transmission of COVID-19 [76].

In January 2020 the World Health Organization recommended an interpersonal distance of $1 \mathrm{~m}$ [77]. Social distancing rules differed between jurisdictions, while other countries used distances such as $1.5 \mathrm{~m}$ in China [78], $2 \mathrm{~m}$ in the United Kingdom [76] and Korea [79], Australia settled on the $1.5 \mathrm{~m}$ rule or an equivalent density of 1 person per 4 sqm [80].

\subsection{Types of Urban Green Spaces Utilised}

Pre-pandemic studies have shown that people generally prefer green spaces that are large and accessible [81-83], as well as of higher quality [82]. The perceived quality of a green space finds expression in perceived biodiversity [84,85], and plant structure and complexity, as well as recreational amenities such as exercise areas or ballfields [83]. It has also been posited that accessibility of urban green spaces has a differentially greater benefit for people at risk (older people, people with poor mental health, people with disability, people with non-communicable diseases etc.) [41]. There are four primary types of parks in the conceptual hierarchy: Pocket Parks, Neighborhood Parks, Community Parks, and Urban Parks [86].

In many established communities, neighborhood parks are not equally distributed but tend to favor the socioeconomically privileged sections of society $[73,87,88]$, with Australian communities being no exception [89]. This becomes particularly poignant during times of movement restrictions and stay-at-home orders [72].

The imposed travel restrictions during the lockdown period resulted in changes to user behavior. Larger and more attractive green spaces at the periphery that were the focus of pre-pandemic visitation [62], were supplanted by the use of urban green spaces in close proximity to the resident's homes [56], even if they were less attractive [61]. Thus the use of urban parks declined, placing additional demand on pocket parks and neighborhood parks. 
While larger public green spaces provide greater physical and mental health benefits (Table 1) [70], even small private garden green spaces saw a greater utilization during the pandemic [62], which made a difference for mental health outcomes [64]. Conversely, people who could not access urban green spaces, either because the parks were closed or because of travel limitations, experienced a sense of deprivation [61,68,71]. including increased incidences of depression and anxiety [38,39].

Table 1. Physical parameters and social use functions of various types of urban green spaces.

\begin{tabular}{|c|c|c|c|c|c|c|c|}
\hline & \multirow{2}{*}{$\begin{array}{c}\text { Semi-Private } \\
\text { Apartment } \\
\text { Complexes }\end{array}$} & \multicolumn{4}{|c|}{ Public General } & \multicolumn{2}{|c|}{ Public Specialist } \\
\hline & & $\begin{array}{l}\text { Pocket } \\
\text { Parks }\end{array}$ & $\begin{array}{c}\text { Neighborhood } \\
\text { Parks }\end{array}$ & $\begin{array}{l}\text { Community } \\
\text { Parks }\end{array}$ & $\begin{array}{l}\text { Urban } \\
\text { Parks }\end{array}$ & $\begin{array}{l}\text { Botanic } \\
\text { Gardens }\end{array}$ & $\begin{array}{l}\text { Green } \\
\text { Corridors }\end{array}$ \\
\hline area (range) (ha) & $0.0-0.2$ & $0.1-1.0$ & $0.5-4.0$ & $2.5-10$ & $>10$ & $0.5-4.0$ & $0.0-1.0$ \\
\hline typical area (ha) & $<0.1$ & $0.1-0.2$ & $2.0-3.0$ & $4-6$ & $>8$ & $2.0-3.0$ & $0.1-0.2$ \\
\hline catchment radius $(\mathrm{m})$ & 100 & $200-300$ & $300-500$ & $500-700$ & $\geq 1000$ & $\geq 1000$ & $300-1000$ \\
\hline shape & rectangle & rectangle & rectangle & rectangle & rectangle & rectangle & linear \\
\hline \multicolumn{8}{|l|}{ Social use function } \\
\hline Playground & $(X)$ & $(\mathrm{X})$ & $x$ & $x$ & $x$ & & \\
\hline picnic tables & $X$ & $X$ & $x$ & $x$ & $X$ & & \\
\hline rest spaces/benches & $x$ & $x$ & $x$ & $x$ & $x$ & $x$ & \\
\hline Barbeques & $(X)$ & & $x$ & $x$ & $x$ & & \\
\hline running trails & & & $x$ & $x$ & $x$ & & $x$ \\
\hline bike paths & & & $x$ & $X$ & $X$ & & $x$ \\
\hline outdoor sport courts & & & $X$ & $x$ & $x$ & & \\
\hline multi-use grass areas & & & $x$ & $x$ & $x$ & & \\
\hline sport fields & & & $x$ & $x$ & $x$ & & \\
\hline nature appreciation & & & $x$ & $x$ & $x$ & $X$ & \\
\hline community food & & & $x$ & $x$ & & & \\
\hline group picnic spaces & & & & $x$ & $x$ & & \\
\hline restrooms & & & & $X$ & $X$ & $X$ & \\
\hline covered spaces & & & & $x$ & $x$ & & \\
\hline event space & & & & $X$ & $X$ & $X$ & \\
\hline public transit access & & & & $x$ & $X$ & $x$ & \\
\hline
\end{tabular}

\subsection{The Australian Situation}

In the Australian pre-COVID setting, accessibility to urban green spaces was correlated with engagement in any recreational activity, while larger, high-quality green spaces within walking distance were conducive to prolonged activity [90,91].

During the various COVID-19 induced lockdown periods in 2020, as enforced either nationwide (March-May) [24,44] or community-/state-wide as the need arose, such as in Melbourne (August-October) [92], outdoor activity was restricted to $1 \mathrm{~h}$ of exercise per day. During the 2021 lockdown in NSW (June-September), outdoor activities were similarly time-restricted in selected 'hot-spot' local government areas, while less time limited in other areas [25-27]. Common to all, however, was that outdoor activities were limited to exercising (including walking dogs) with one person from another household (socially distanced) or with multiple members of the same household [24,27]. Utilization of beaches was permitted, as long as they were used for exercise rather than recreation and relaxation $[24,27]$. In the non-lockdown period, social distancing rules applied, which terminated or severely restricted some community sports as well as outdoor adventure activities [12].

An examination of attitudes to green spaces and their utilization in October 2020 compared various metropolitan and regional Australian communities. Of particular relevance is the comparison of Melbourne, a metropolitan community of 4.9 million people in lockdown, with Sydney, a metropolitan community of 5.2 million people not in lockdown, but subject to social distancing rules (e.g., 1 person $/ 4$ sqm). People in lockdown reported an increased visitation of green spaces, for longer periods of time (cumulative), with greater 
levels of perceived benefits, not only in terms of physical exercise, but also in terms of solace/respite and an increased sense of connectedness with neighbors [93]. Broadly similar patterns, with particular emphasis on the physical and mental health benefits, were observed by other authors for Brisbane, a metropolitan community of 2.6 million people [94] and Perth, a metropolitan community of 2.1 million people [68].

The COVID pandemic brought about a greater use of green spaces in the metropolitan centers compared with the regional communities in their state [93], suggesting that lockdowns and social distancing have a greater mental health impact on people in high-density urbanized centers than on communities in regional settings.

In broad terms, the study also examined changes to the utilization of green spaces caused by COVID-19, noting that green spaces close by were preferred, but that the pandemic also created a desire to discover green spaces further afield. As the study did not included a qualitative component exploring motivations, it is unclear whether this is due to a desire for novelty and variation, or whether the green spaces close-by were perceived to be lacking in attributes.

People working from home were more likely to use green spaces, to utilize them more often and for longer periods for respite and exercise and were also more likely to discover previously unvisited green spaces. Significant, unanticipated findings were that a decreased use of green spaces was correlated with the perceived financial situation. People experiencing increased financial difficulty due to the COVID situation were less likely to utilise green spaces and found them less relevant to stay connected with neighbours, to find respite or to conduct exercise [93]. This repeats observations made in pre-pandemic times [89], suggesting that underlying spatial patterns of residence may play a role, as people experiencing increased financial difficulty tended to live in areas where it took longer to reach an urban green space.

A study by Dushkova et al. examined the perceived future demand for urban green spaces as a result of the experiences during the pandemic. For Perth residents, more street greening $(77 \%)$ was the top priority, followed by natural bushland $(60 \%)$. More than $40 \%$ of the respondensts argued for more pocket parks, more green spaces close to home, more community gardens and more greening of front yards [68]. In terms of public park infrastructure, more seating (benches) and more shelter/shade were deemed desirable [68].

\section{Discussion}

Very early in the pandemic, when the various enforced lockdowns showed the desired decrease in human activity $[95,96]$, the future design and re-design of urban public spaces came into focus [16]. Both the social distancing rules imposed by public health departments and COVID-19 induced revisions of personal preferences of inter-personal spaces have an impact on use of public spaces, in particular perceptions of 'crowding' and the perceived associated transmission risks [54,97-99].

There is a need to consider how to future-proof the urban green space to make it fitfor-purpose when the next pandemic strikes. This future-proofing should encompass both temporary (to be activated during a pandemic) and permanent solutions (to be considered in the design of new green spaces and the redesign of existing urban parks). The following discussion will examine the provision and design of future green spaces by considering the planning context, together with suggested solutions. Given the nature of a rapidly developing pandemic, the solutions need to be both temporary, ad-hoc and reactive designs that can be implemented as and when the need arises, and long-term adjustments that need to be incorporated in the planning for future new or redeveloped green spaces.

These proposed solutions are based on a review of the above-described experiences under COVID-19 and are also informed by the ad-hoc solutions espoused by the various communities. Any dimensions, where presented, assume the same social distancing parameters as were in force in Australia for the COVID-19 pandemic, i.e., $1.5 \mathrm{~m}$ horizontal distance with a density of 1 person $/ 4 \mathrm{~m}^{2}$. 


\subsection{Planning Context}

In the constitutional setting of the Commonwealth of Australia, land management and thus urban planning, is the prerogative of the states, where the state legislation sets the minimum standards which can be, but are rarely exceeded by local government $[100,101]$. The development requirements are spelled out in Development Control Plans [102], which where possible, make reference to Australian standards. These standards were developed in pre-pandemic times and generally only stipulate minimum requirements. In most instances, developers have little incentive to exceed the requirements as that would impinge on their economic bottom line. In consequence, most suburban developments deliver pocket parks (Figure 1), residual token habitats (Figure 2A) or green spaces derived from planning changes (Figure 2B).

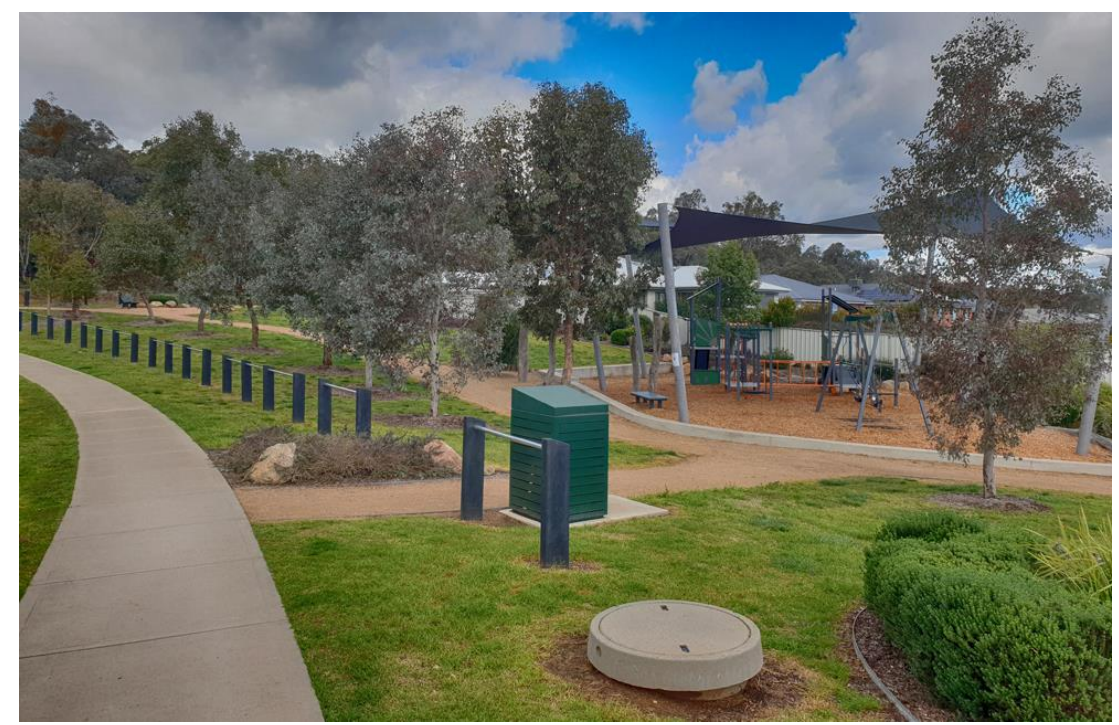

(A)

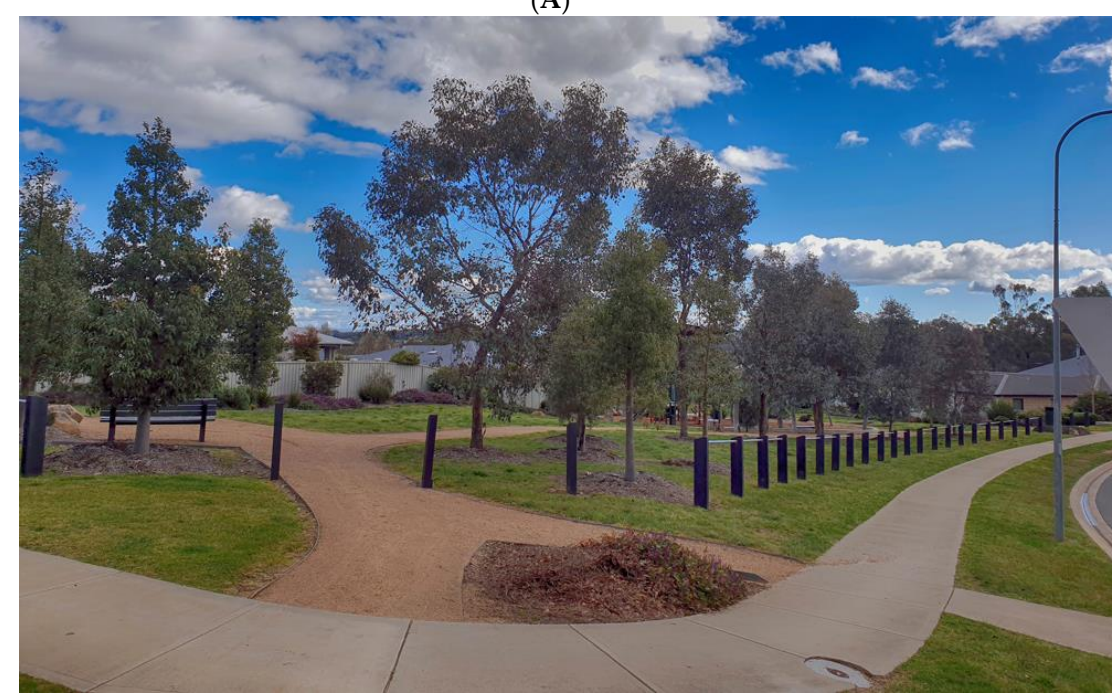

(B)

Figure 1. Example of a pocket park in a new housing development (Fairway Gardens, Thurgoona NSW). (A) view from west; (B) view from east. 


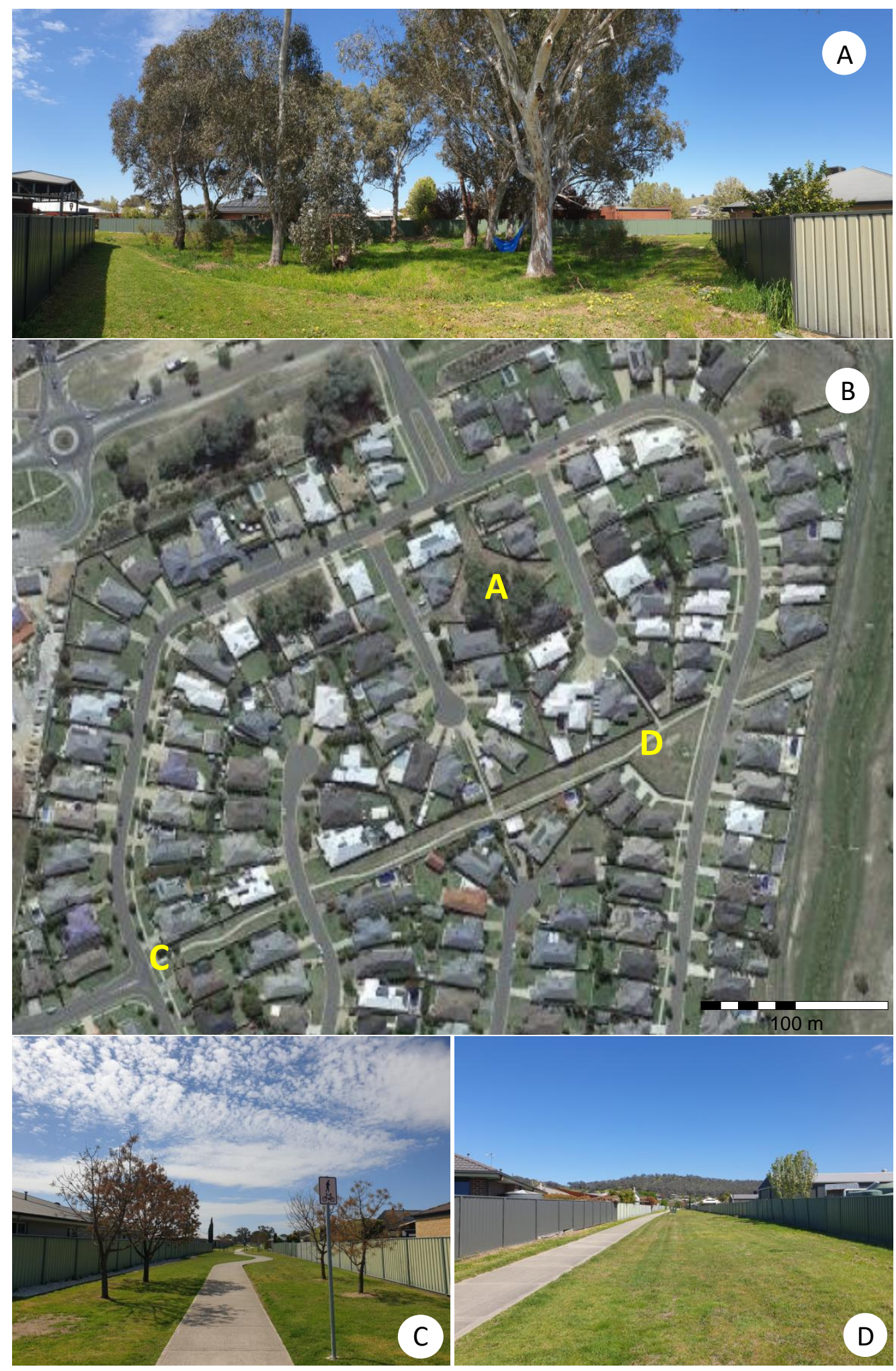

Figure 2. Examples of developer-driven urban green spaces. (A) residual, undeveloped green space maintained as token habitat; (B) aerial view of the north-eastern section of Eastern View estate, Albury, NSW; (C) supernumerary roadway converted into an undeveloped linear green space seen from the west; (D) seen from the east. 
Suburban development in Australia is carried out, for the most part, on a piecemeal basis where one parcel of peri-urban farmland is converted by its owner or by a developer into housing allotments. To maximize profits, housing block sizes are as small as permissible under the local zoning and subdivision regulations and any green space provision tends to occur based on a bare-minimum compliance with requirements. As the urban sprawl continues, adjacent parcels of farmland will be likewise partitioned. Unless the local government acquires a section of farmland for conversion into a large designed green space, the result will be conglomerates of dense housing estates with pocket parks, which are often situated on land that is otherwise undesirable for housing. On occasion, a preexisting green space may have been reserved in the past (usually the nineteenth or early twentieth century) for purposes such as water conservation (along creek lines) or as part of travelling stock reserves $[103,104]$. While these may be converted into amenity spaces, the extent of this conversion will be governed by the gazetted nature of the reserve, which may limit its use to recreational pathways and seating, but may exclude sporting fields or multipurpose lawns.

\subsection{Temporary, ad-hoc Solutions}

As the onset of the COVID-19 pandemic was effectively instant in terms of the timelines of urban planning, local government authorities were forced to engage in a range of $a d-h o c$ solutions to the emerging demand. Some of these are informative for longer term planning of post-pandemic urban green spaces.

\subsubsection{Provision of Pandemic-Sensitive Exercise Spaces}

During the pandemic, some communities counter-balanced the closure of local urban parks as recreational spaces by expanding on the concept of "Sunday-Streets" [105] and declaring some neighborhood streets as 'shared streets' or 'slow streets' where pedestrian use had priority over vehicular use $[14,73,74]$, or by closing streets for vehicular use altogether. This needs to be carefully managed and not initiated as an ad-hoc solution in order to avoid inadvertent social inequalities, as experiences in North America have shown $[73,106,107]$. Such temporary traffic restrictions allowed for physical exercise in the form of walking and jogging, albeit without the mental health benefits provided by green spaces.

\subsubsection{Provision of Pandemic-Sensitive Restorative Places}

Even though urban green spaces were perceived as significant restorative places especially during the pandemic [54-56,70,93,94], several communities closed off their local parks, in particular the smaller parks, due to a perceived or actual crowding when these parks served as proxy social venues [54,66,73-75]. Other communities responded differently, engaging in tactical urbanism by providing immediate relief by adapting public spaces [108]. A common scheme was to provide social distancing bubbles painted on lawns (Figure 3) [108,109], or lawns mowed in checkerboard patterns (Figure 4) [110,111]. Social distancing measures, as indicated by such means, were by and large effective, but painted circles were indicative only, relying on voluntary adherence. The absence of physicality in this design allowed for spatial creep, as is evidenced in a number of images taken by onlookers (Figure 3) [112].

\subsection{Long-Term Planning Adjustments}

One of the key considerations in future-proofing urban space use during future pandemics will be the extent to which people-friendly urban green spaces are integrated with other urban design considerations, in particular in terms of heat effects and universal access designs. Designed urban green spaces in new housing developments tend to be developed from the ground up, in most instances without any remnant larger vegetation. Consequentially, the choice of vegetation required for shade, micro-climatic provisioning, spatial separation (see below) and visual appeal, will be driven by balancing biodiversity 
against amenity values. While in the Australian setting the benefits of native species restoration are often advocated, there are also voices that argue that developed urban and suburban areas are novel ecosystems [113,114], and that it is possible to enhance these through strategic planting of exotic species that provide food and habitat opportunities for both native and exotic animal species [115]. To alleviate the slow establishment of shade trees, plant selection may need to be chronologically stratified and could consider, in the first instance, species that are eminently transplantable as mature species, such as some palm varieties [116].
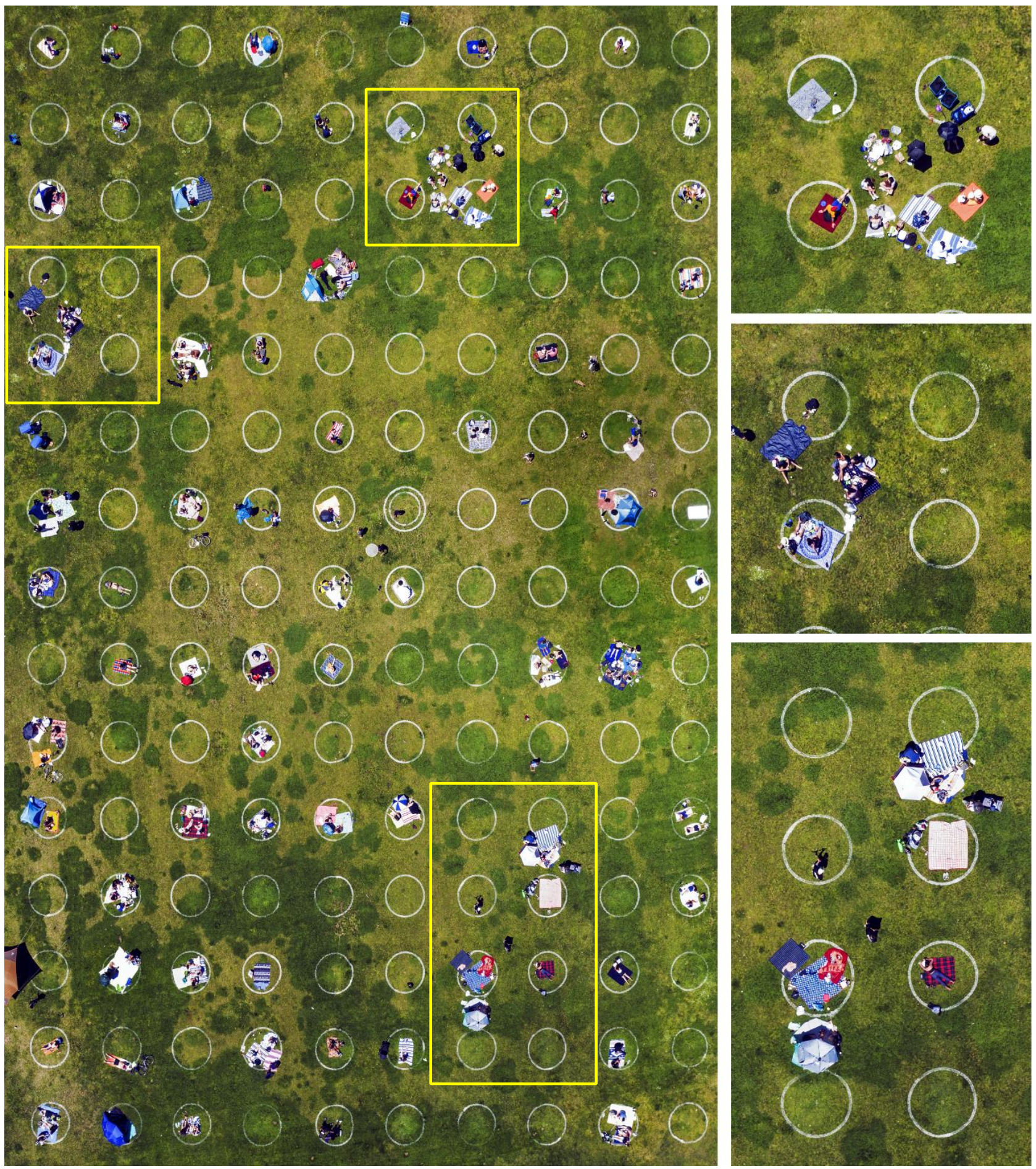

Figure 3. Ad-hoc solution for social distancing in an urban green space at Mission Dolores Park, San Francisco. (Photo Christopher Michel via WikimediaCommons). 
Derived from sources on the hierarchy of urban green spaces $[86,117,118]$, and informed by the literature on their physical and the mental health benefits [49-53], Table 1 sets out the amenity provision of a range of several types of urban and peri-urban green spaces. Obviously, the larger the park, the more space exists for a diversity of amenity options it can provide. Table 2 summarizes the contributions of the various types of public green spaces to the mental and physical health of residents, with particular relevance to periods of a pandemic.

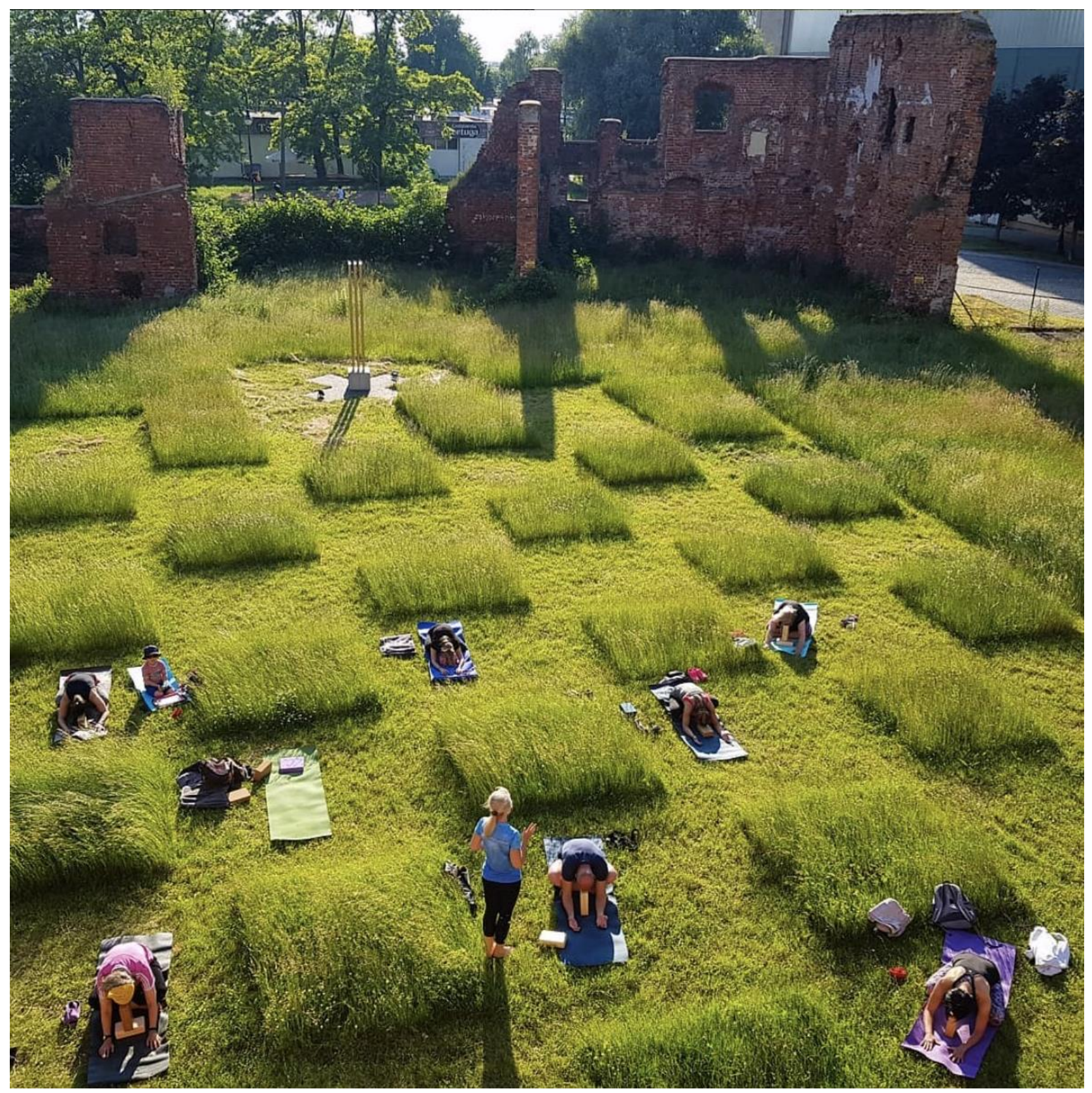

Figure 4. Ad-hoc solution for social distancing in an urban green space. "Social distancing lawn" created by the Galeria EL Art Centre in Elblagg, Poland. (Image reproduced with permission Łukasz Kotyński). 
Table 2. The contribution of various types public green spaces to the mental and physical health of residents during pandemics.

\begin{tabular}{ccccc}
\hline & \multicolumn{2}{c}{ Mental Health } & \multicolumn{2}{c}{ Physical Health } \\
\cline { 2 - 5 } & Personal & Social & Low Level Exercise & High Level Exercise \\
\hline Private Garden & $X$ & & gardening & \\
Condominium Garden & $X$ & $X$ & calisthenics & running, cycling \\
Pocket Park & $X$ & $X$ & gardening & running \\
Neighborhood/Community Garden & $X$ & $X$ & walking & running, MBK \\
Green Corridor & $X$ & $X$ & walking & running \\
Botanic Garden & $X$ & $X$ & walking & running \\
Landscaped Parkland & $X$ & $X$ & walking & running, swimming \\
Remnant Bushland & $X$ & $X$ & walking, swimming & walking \\
Riverine margin & $X$ & $X$ & walking, swimming & running, cycling \\
Coastal waterfront & $X$ & $X$ & walking & \\
Beach & $X$ & $X$ & $X$ &
\end{tabular}

MBK-mountain bike riding.

Future master planning for the provision of urban green spaces needs to consider a stratified matrix of urban parks, ranging from pocket parks to urban parks (Table 2). The permissible personal mobility range in times of a pandemic has a direct influence on urban green spaces access, which needs to be factored into this planning. In the Australian setting, for example, personal exercise was permitted even during lockdown (although often time restricted), but such movement had to occur within $5 \mathrm{~km}$ of the person's residence [24,27]. While in non-pandemic times a single larger neighborhood or smaller community park is more conducive to physical activity in general than many smaller parks as it offers a greater diversity of options [81], the time-distance restrictions during COVID-2x may again prevent many people from utilizing such spaces. Consequently, the future planning strategy should also include actions directed at improving the attractiveness of smaller parks and their suitability for social distancing if the need arises, as well as the conceptualization and pre-planning of ad-hoc spaces.

\subsubsection{Spaces for Physical Exercise}

The majority of urban green spaces suitable for physical exercise are larger neighborhood and community parks, some of which have formal sporting facilities and running/bicycling tracks. While many pocket parks cater for young children with the provision of a playground, young adolescents are often overlooked. Consideration should be given to the establishment of half courts for basketball and netball, which can be readily installed in many pocket parks as can outdoor gym equipment, climbing walls, and installations for bouldering. While value adding in non-pandemic times, this bouldering and outdoor gym equipment does not provide exercise opportunities during the times of a pandemic as many councils immediately closed off gym and bouldering equipment during the COVID-19 pandemic due to fear of virus transmission via contaminated surfaces [119]. Outdoor basketball/netball courts, on the other hand, remained open and provided an avenue for youth sport in times when normal community sport was suspended [120].

Given aerosol transmission of SARS-CoV-type viruses, it is important to consider not only the social distancing requirements of stationary and slow-moving individuals but also that of people moving at faster speeds, such as runners of cyclists. In these cases distancing intervals of $10 \mathrm{~m}$ are indicated [121]. While this is primarily a matter of public education, it also has implications for the design of running tracks if crowding is to be avoided. 'Traffic' separation measures, such as lane markings on the ground, be it via paint or physical means (miniature green strip) may need to be considered, as is the creation of a dedicated running/cycling track where slow-moving pedestrian traffic is discouraged. 


\subsubsection{Spaces for Mental Recreation}

The traditional use of small neighborhood/pocket parks is to serve as a venue for neighborhood exchange and communication and to provide an opportunity for small children to recreate in playgrounds. Often, they are also the locations of a children's playground. As noted above, especially on modern housing estates, pocket parks tend to be located on pieces of land that are deemed unsuitable for other purposes rather than at locations that are best suited for the community and its activities. In New Zealand, consideration is given to develop additional pocket parks where possible [108].

One of the main concerns during lockdown was illicit socializing while outdoors, with the inherent risk of social distancing not being observed. While in larger parks ad-hoc social distancing circles could be established, some community authorities closed the smaller pocket parks due to perceived or actual crowding when these parks served as proxy social venues $[54,66,73]$. The enforced lockdown, with prolonged periods indoors, coupled with socializing being limited to video-conferencing and phone calls, caused social isolation [36] and exacerbated pre-existing mental health issues. The ad-hoc solutions of painted circles or differential mowing still entailed the risk of intentional commingling as well as spatial creep (Figure 3).

While in general over-designed spaces should be avoided in favor of more 'organic' approaches [108], the need for social distancing requires some planning rigor if a pocket park shall function as a mental and physical recreation space. Possible design concepts are shown in Figure 5. The dimensions of these are based on the social distancing parameters as were in force in Australia for the COVID-19 pandemic, i.e., $1.5 \mathrm{~m}$ horizontal distance between people, with a density of 1 person $/ 4 \mathrm{~m}^{2}$ (unless they are members of the same household).

The design concepts comprise well defined social pods, each $4 \times 4 \mathrm{~m}$, which are confined by low, but non-traversable $1.8 \mathrm{~m}$ wide plantings. To prevent people from pushing through the planting from one pod to the next, it may be necessary to install a fence midway. The plantings should be about $1.2 \mathrm{~m}$ high, which will provide privacy while seated or lying down, yet allows for social communication across the planting when standing. In order to reduce the likelihood of inadvertent mingling, the entrances to these social pods should ideally not come off the same path to prevent children readily running from one pod to the adjacent one. Figure 5 shows some of the many possible configurations. While quite formal in their structure, these social pods are not being envisaged as replacements of a pocket park but as value-adding components, for example at the park's periphery.

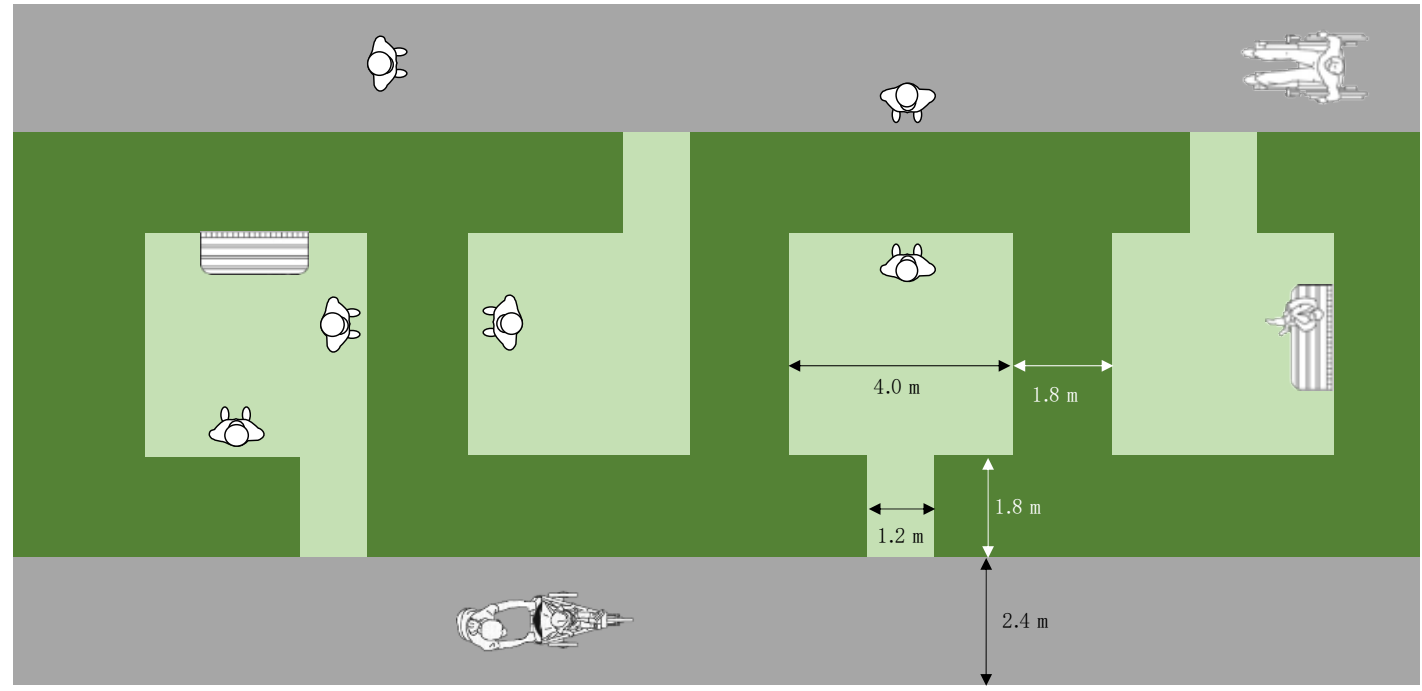

(a)

Figure 5. Cont. 


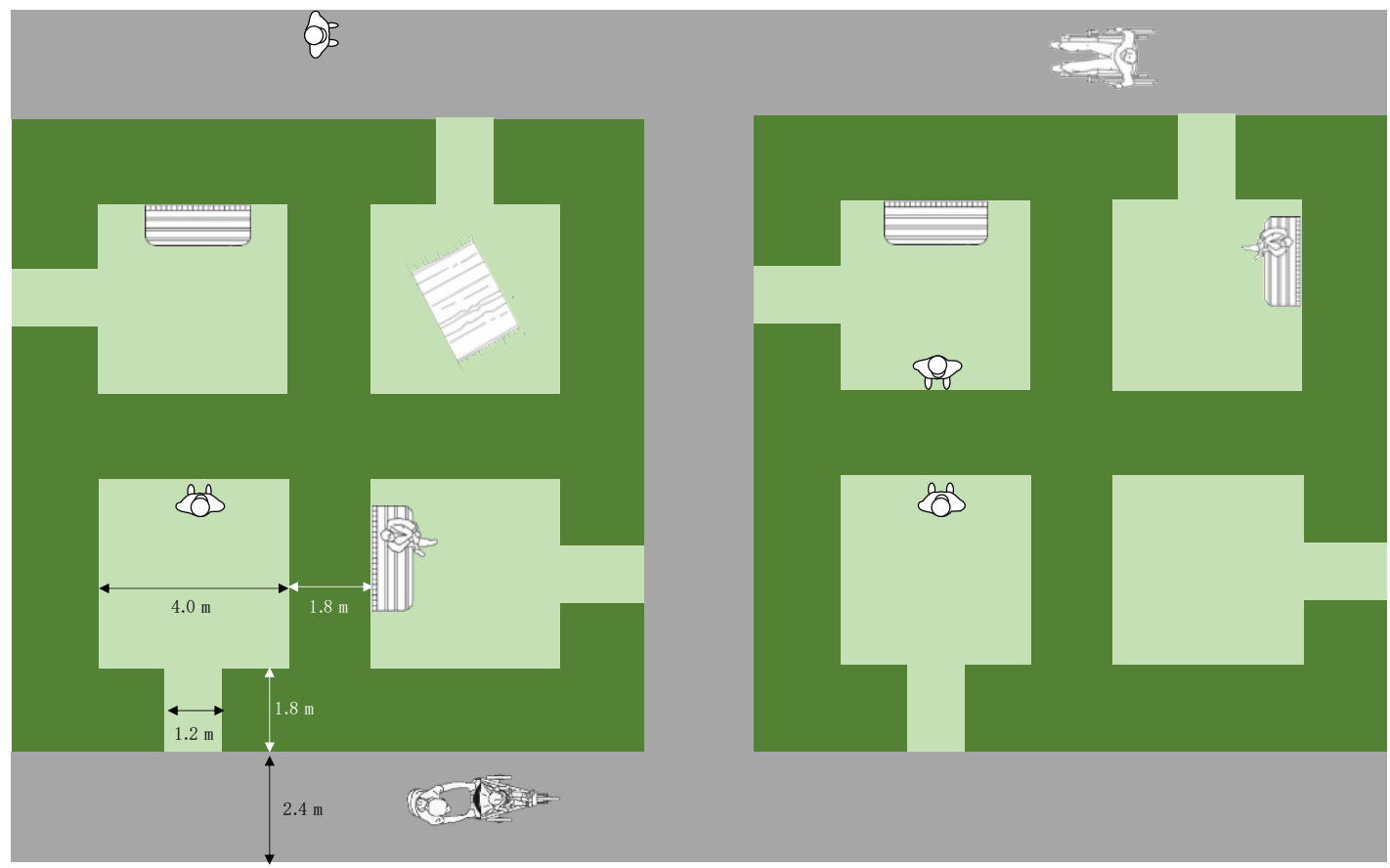

(b)

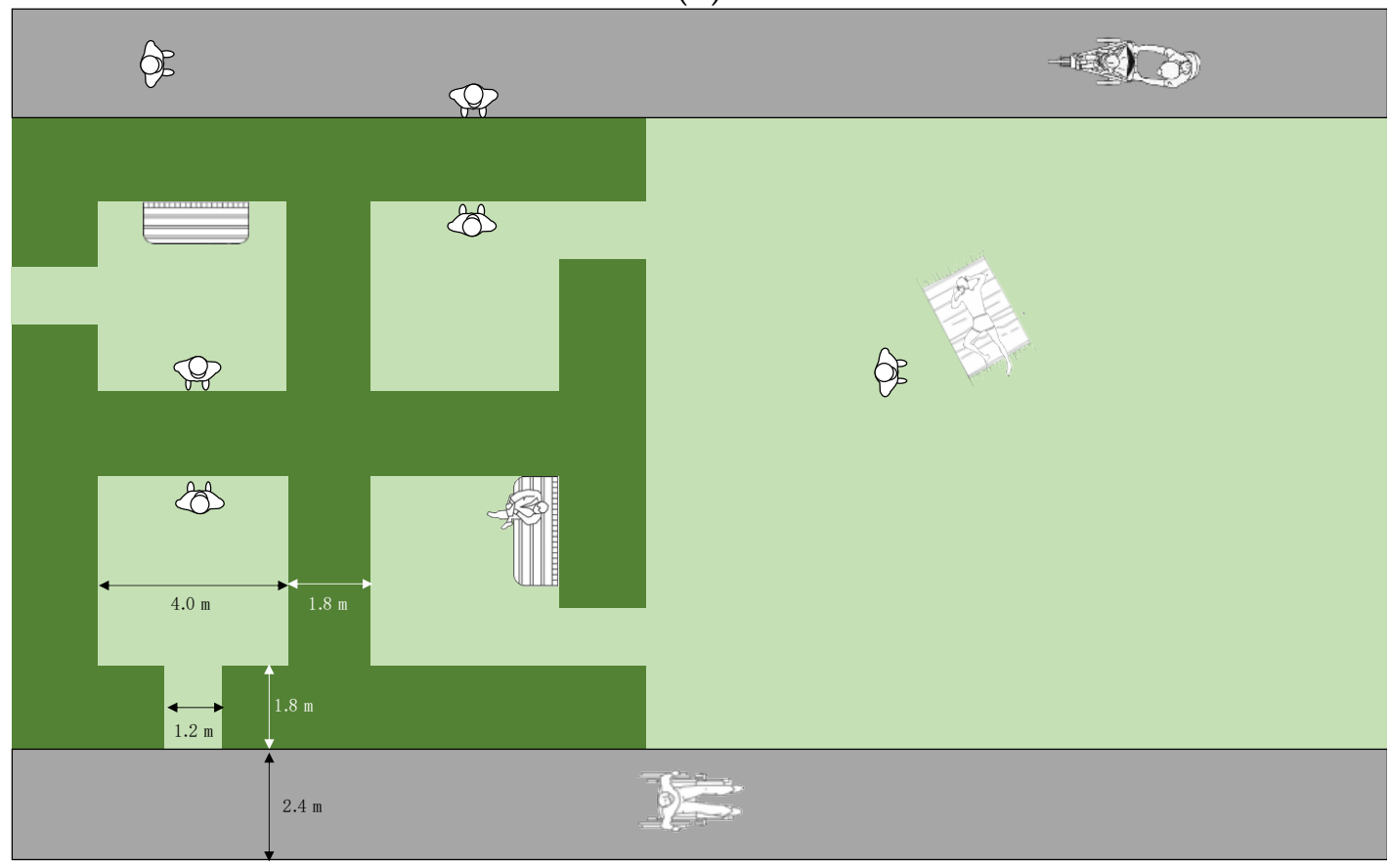

(c)

Figure 5. Design concepts for value-adding to pocket parks. (a) Design for narrow, sub-optimal green-spaces. (b) Compact design of $2 \times 2$ spaces with intermediate communications pathway (c) Compact design of $2 \times 2$ spaces adjacent to an open green space. 


\subsubsection{Conceptualizing ad-hoc Spaces for Mental Recreation}

As noted earlier, during the COVID-19 pandemic, numerous councils converted open park spaces, as well as community sporting fields, into ad-hoc recreational spaces by applying painted circles as social distancing devices (Figure 3). A perusal of imagery posited on social media sites (Flickr, Instagram, Facebook) shows that some of these were taken up by large numbers, creating a high density of people, socially distanced while sedentary, but mingling and passing each other on the way to and from the venues.

Depending on the contagiousness of COVID- $2 x$ and a personal acceptance of recreating in crowded areas during times of a pandemic [122,123], such large venues may be intimidating for some citizens. In addition, the relative walking distance to the larger green spaces, which tend to be fewer in number, can act as an inhibitor. Consideration should be given to alternative, ad-hoc place activation.

The place activation project undertaken by the City of Christchurch (New Zealand) following the 2011 earthquake has demonstrated a range of innovative uses of vacant blocks and other open spaces $[124,125]$. Historically, informal urban green spaces on vacant blocks played a major role [126], but these have been declining due to rising land prices and a development boom. While some of these still exist, and thus could form the basis for temporary pocket parks, individual ownership and issues of public liability tend to mitigate against their use.

In planning for COVID-2x, however, councils can invest efforts into negotiating access to such spaces in times of demand. For example, local councils can amend their development control plans to the effect that owners applying to demolish extant structures either need to commence building within a set period, such as eight to ten weeks, or make good the allotment by levelling the ground and establishing a cover of pasture grasses until such time that construction commences. Moreover, it is conceivable to include in the respective development approval a stipulation that the local council could convert the vacant land into an ad-hoc pocket park for the duration of the pandemic.

In addition, with lockdown reducing car traffic and consequently demand for parking spaces, consideration should be given to temporarily convert such spaces into 'parklets.' This concept of popup parks exists in some communities (Figure 6) [127-130]. Facilitated by artificial turf, these concepts do not have the same amenity values as 'real' turf but at the same time can be rapidly deployed using low concrete planters, with a shade tree (in a planter) in the center and protected by traffic barriers from the passing one-way traffic (Figure 7). That model can be readily varied, by reducing the number of compartments and adding a running/jogging track, for example (Figure 8).
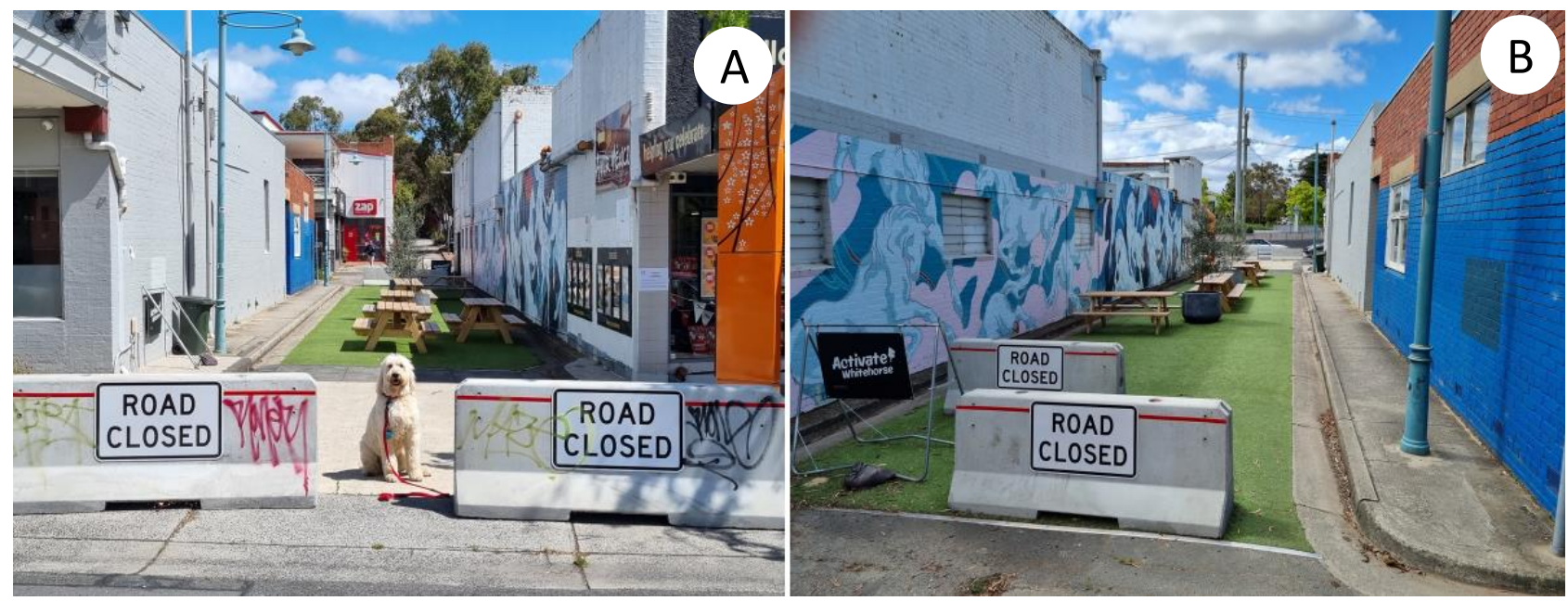

Figure 6. Blocked-off street section to create a temporary 'parklet' in the City of Whitehorse (Vic.). (A) as seen from the main road; (B) as seen from the neighborhood road. 


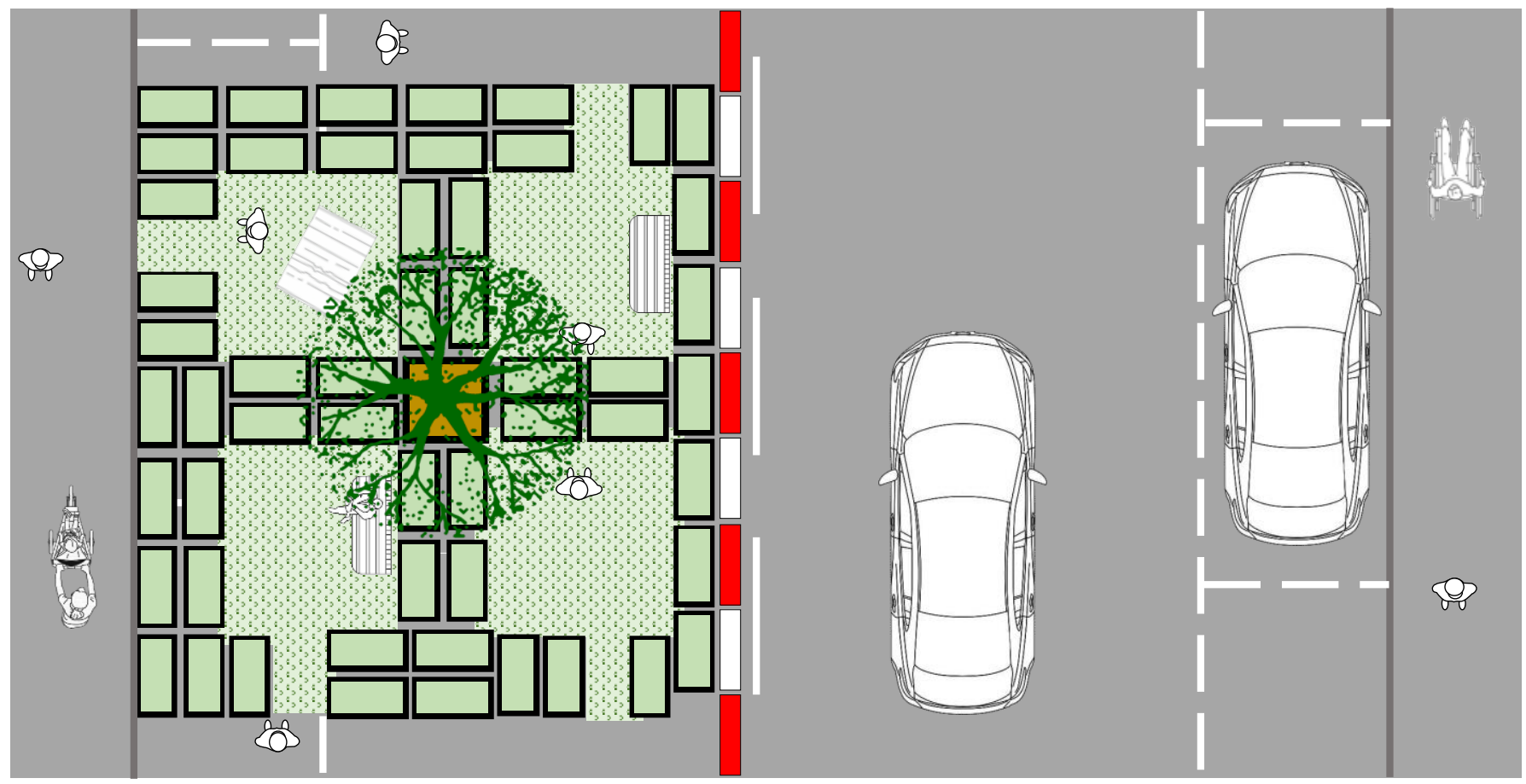

Figure 7. Design concept for an ad-hoc, socially distanced 'parklet' on a quietened street.

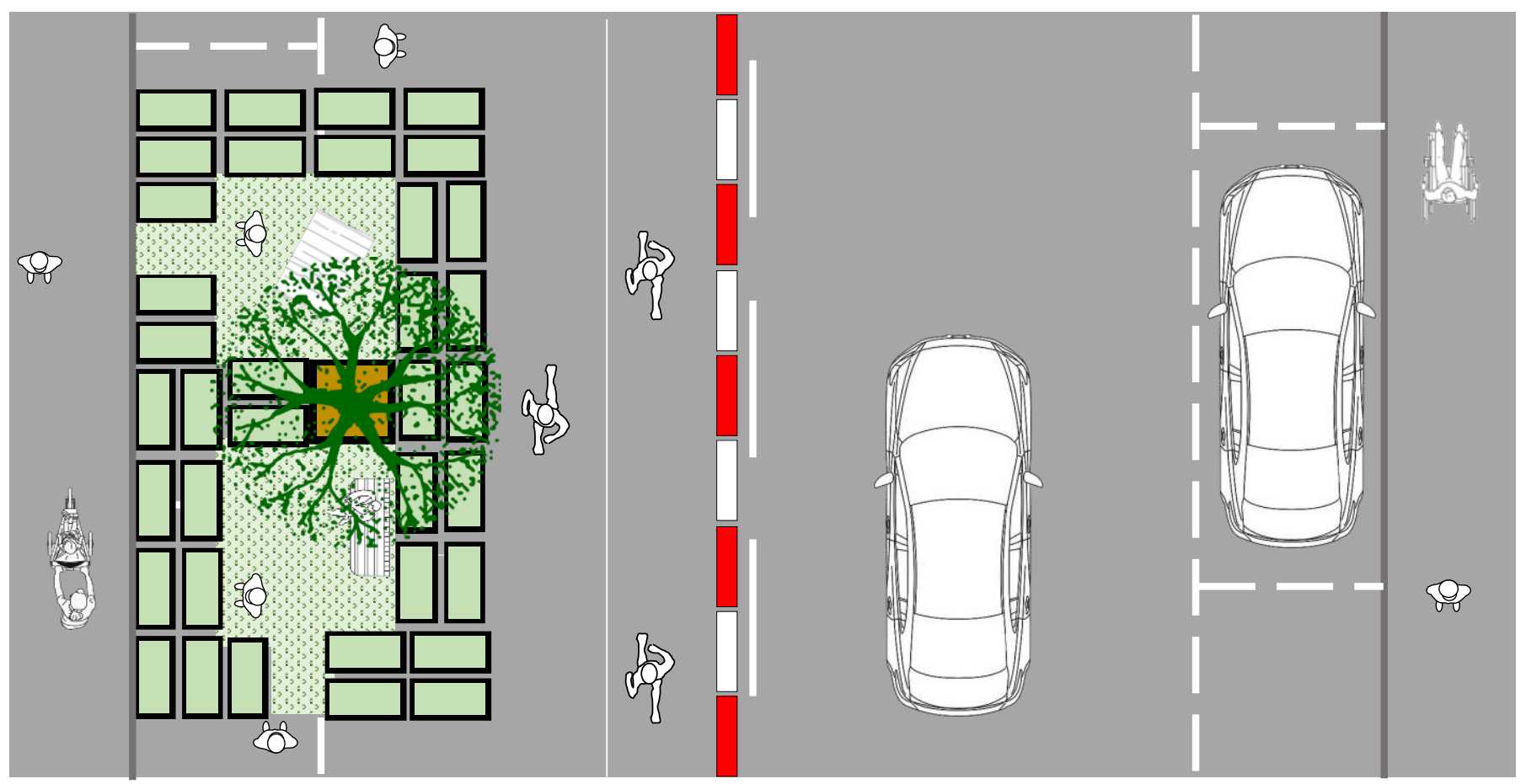

Figure 8. Design concept for an ad-hoc, socially distanced 'parklet' and jogging track on a quietened street.

The feasibility and practical implementation of such ad-hoc spaces can be trialed (and practiced) in an annual Park(ing) week event, fashioned along the lines of San Francisco's ‘Park(ing) day' [130].

\subsubsection{Communication Corridors}

Building on this concept, future urban green space planning needs to incorporate green corridors that connect park-like green spaces with each other and thus allow runners 
to exercise within a mandated radius from their homes and provide visual diversity for walkers. While temporary street closures (see above) can be a solution, the concern associated with such corridors is that highly connected green spaces have shown to increase the risk of transmission [76]. As the SARS-CoV-2 mutated into different strains, some of these, in particular the Delta strain, have proven highly infectious with transmission even by fleeting, passing contact, with a person passing through the aerosol cloud emitted by an infected person [131,132].

The effect environmental features have on the 'walkability' of a neighborhood [133,134] is a significant element [82,134], which attains much greater significance in the time of a pandemic [135]. Participant observation, anecdotal evidence and an examination of the media coverage during the various lockdown periods in NSW and Victoria showed that a considerable number of people exercised in the permitted pairs, whereby exercise ranged from sedate walking a dog, to strenuous running. This occurred along footpaths and mixed pedestrian/bike trails in the built-up areas of the central business district (CBD), in suburbia and in the urban periphery.

While footpaths in the CBD were usually wide enough to accommodate 2 people walking side-by-side with $1.5 \mathrm{~m}$ spacing for social distancing, as well as to accommodate oncoming pedestrian traffic, the footpath spacing in suburban settings, usually confined to 1 side of the road, was too narrow. While the absolute minimum width of a foot path is $1.0 \mathrm{~m} \mathrm{[136]} \mathrm{the} \mathrm{mandated} \mathrm{width} \mathrm{of} \mathrm{low-volume} \mathrm{suburban} \mathrm{footpaths} \mathrm{ranges} \mathrm{from}$ $1.2 \mathrm{~m}$ in the Australian Capital Territory (ACT), NSW, Queensland and Western Australia (Figure 9a) [137-139].

In terms of universal design, the absolute minimum for 2 wheelchairs to pass is $1.5 \mathrm{~m}$ [136] with $1.8 \mathrm{~m}$ recommended [139]. Shared Use Paths/Cycle paths, which are commonly only established as trunk paths, have a recommended width of $2.0 \mathrm{~m}$ in NSW and $2.5 \mathrm{~m}$ in the ACT $[137,138]$.

Given an average body width of $0.6 \mathrm{~m}$ [136] and a minimum social distancing spacing of $1.5 \mathrm{~m}$, a COVID-safe footpath should be at a minimum $2.0 \mathrm{~m}$ wide, which would force people to walk too close to the edge of the path (Figure 9b). This can be avoided with a minimum width of $2.2 \mathrm{~m}$ (Figure 9c), while a width of $2.4 \mathrm{~m}$ provides sufficient space (Figure 9d). The latter also allows for a pedestrian and a person pushing a stroller to walk side-by-side while maintaining social distancing (Figure 9e). To allow for a safe movement, a person in a wheelchair requires a $1.2 \mathrm{~m}$ clear path [136], which is possible on a $2.4 \mathrm{~m}$ wide path, but more adequate on a $2.6 \mathrm{~m}$ wide footpath (Figure 8). This width is the same as the width recommended for trunk paths [137]. For 2 people in wheelchairs to exercise together while maintaining social distancing, a footpath width of $2.8 \mathrm{~m}$ would be ideal (Figure 9g), but a width of $2.6 \mathrm{~m}$ is manageable. Finally, this width also allows for the safe passing of single bi-directional traffic while maintaining social distancing without the need to step off the footpath.

At present, the design of many suburban developments calls for a uniform curb-toboundary setback (nature strip) on both sides of a roadway, depending on the size of the property. In NSW, for example, that setback is $4.5 \mathrm{~m}$ for properties between $300 \mathrm{~m}^{2}$ and $900 \mathrm{~m}^{2}$ and $6.5 \mathrm{~m}$ for properties between $900 \mathrm{~m}^{2}$ and $1500 \mathrm{~m}^{2}$, which encompasses the typical 'quarter-acre block.' [140]. Such a width, however, makes it difficult to accommodate the wider footpaths discussed above. Consideration should therefore be given to designing nature strips of different widths favoring one side of the roadway. Such provisions are already allowable under the development control plans of some councils [141,142], but are not standard practice.

In the Australian setting, with hot summers prevailing in the warm temperate zone, shading of such communication corridors is essential for the amenity of the users. In recent years, increasing attention has been paid to the heat islands generated by built-up urban areas, and the mitigating effects brought about by urban greening [143,144]. 


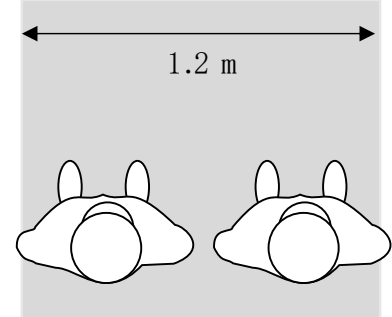

a
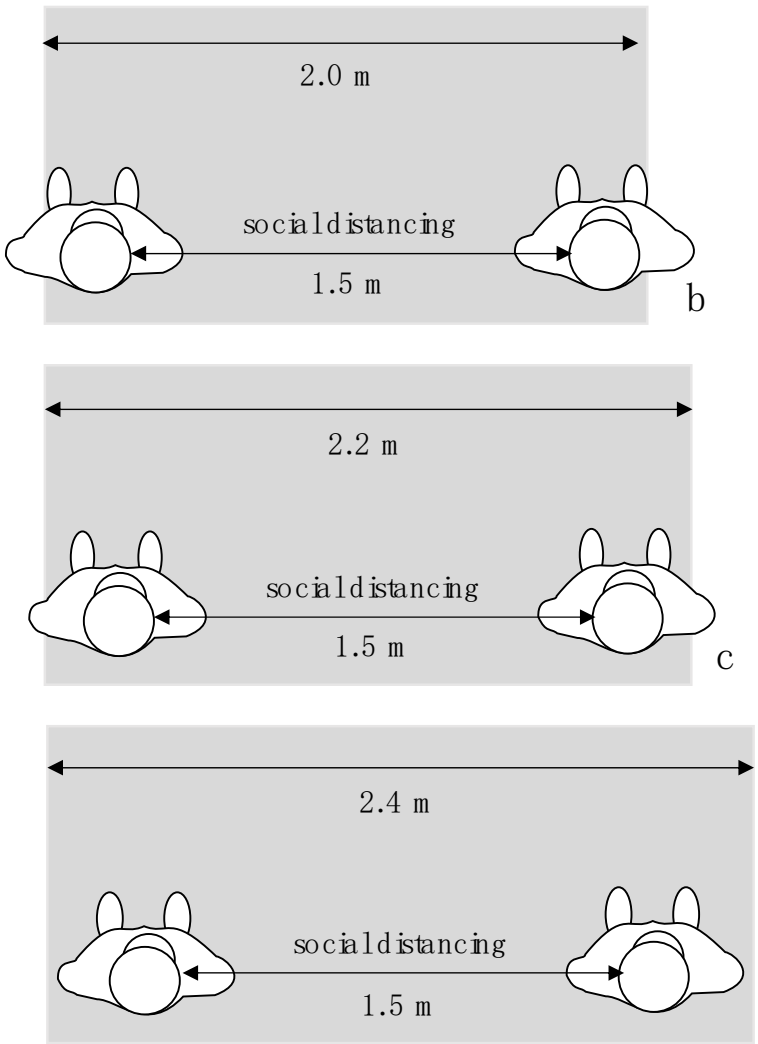

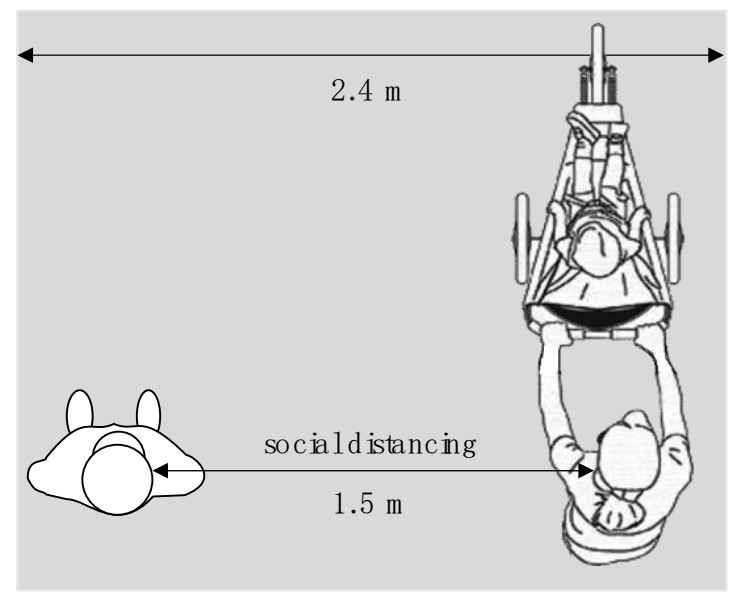

e
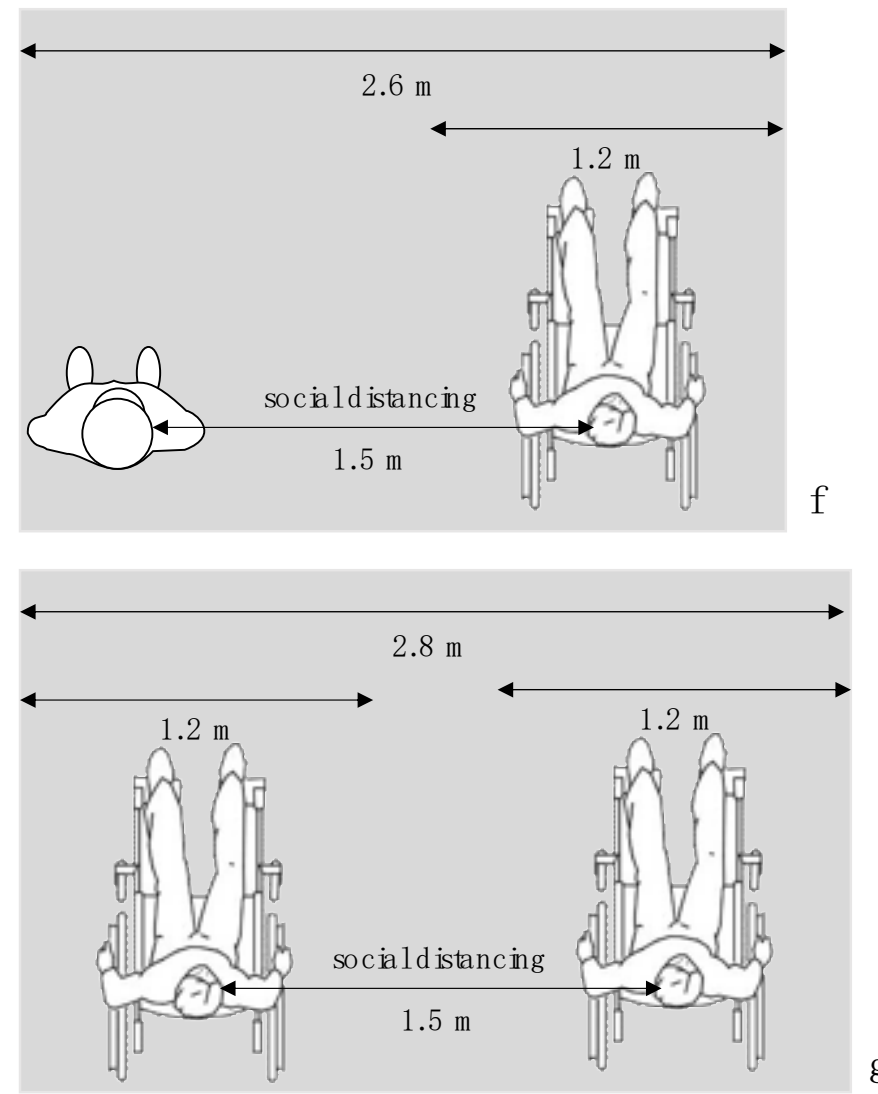

Figure 9. Implications of different widths of footpaths for pedestrians. (a-g) see text.

\section{Outlook}

COVID-19 has been a major cross-sectoral disruptor, affecting how people interact with their physical and social environment. Urban green spaces attained great relevance for maintaining physical and mental health during the periods of lockdowns as well as during the times when personal movement was restricted due to border closures and other travel restrictions. With other zoonotic coronaviruses akin to SARS-CoV-2 currently in existence in various host species, it is only a question of when humanity is faced with another epidemic that may develop into a global pandemic.

Given the role urban green spaces generally play in people's physical and mental health, and given the increased importance that this plays during the times of a pandemic, it is incumbent on urban planners to future-proof their communities by developing a 
strategy that places urban green spaces at the center of a public health strategy. As some of this may involve the modification of planning regulations, the time to act is now.

Funding: This research received no external funding.

Institutional Review Board Statement: Not applicable.

Data Availability Statement: Not applicable.

Conflicts of Interest: The author declares no conflict of interest.

\section{References}

1. WHO. Naming the Coronavirus Disease (COVID-19) and the Virus That Causes It. Available online: https://www.who.int/emer gencies/diseases/novel-coronavirus-2019/technical-guidance/naming-the-coronavirus-disease-(covid-2019)-and-the-virusthat-causes-it (accessed on 10 August 2020).

2. Ritchie, H.; Ortiz-Ospina, E.; Beltekian, D.; Mathieu, E.; Hasell, J.; Macdonald, B.; Giattino, C.; Roser, M. Coronavirus (COVID-19) Cases. Our World in Data. Available online: https:/ / ourworldindata.org/covid-cases (accessed on 25 January 2021).

3. Spreeuwenberg, P.; Kroneman, M.; Paget, J. Reassessing the global mortality burden of the 1918 influenza pandemic. Am. J. Epidemiol. 2018, 187, 2561-2567. [CrossRef]

4. Ritchie, H.; Ortiz-Ospina, E.; Beltekian, D.; Mathieu, E.; Hasell, J.; Macdonald, B.; Giattino, C.; Appel, C.; Rodés-Guirao, L.; Roser, M. Coronavirus Pandemic (COVID-19). Available online: https: / / ourworldindata.org/coronavirus (accessed on 31 August 2021).

5. Ye, Z.-W.; Yuan, S.; Yuen, K.-S.; Fung, S.-Y.; Chan, C.-P.; Jin, D.-Y. Zoonotic origins of human coronaviruses. Int. J. Biol. Sci. 2020, 16, 1686. [CrossRef] [PubMed]

6. Wang, L.-F.; Anderson, D.E.; Mackenzie, J.S.; Merson, M.H. From Hendra to Wuhan: What has been learned in responding to emerging zoonotic viruses. Lancet 2020, 395, e33-e34. [CrossRef]

7. Peeri, N.C.; Shrestha, N.; Rahman, M.S.; Zaki, R.; Tan, Z.; Bibi, S.; Baghbanzadeh, M.; Aghamohammadi, N.; Zhang, W.; Haque, U. The SARS, MERS and novel coronavirus (COVID-19) epidemics, the newest and biggest global health threats: What lessons have we learned? Int. J. Epidemiol. 2020, 49, 717-726. [CrossRef] [PubMed]

8. Spennemann, D.H.R. Residential Architecture in a post-pandemic world: Implications of COVID-19 for new construction and for adapting heritage buildings. J. Green Build. 2021, 16, 199-215. [CrossRef]

9. Kramer, A.; Kramer, K.Z. The potential impact of the Covid-19 pandemic on occupational status, work from home, and occupational mobility. J. Vocat. Behav. 2020, 119, 103442. [CrossRef]

10. Musselwhite, C.; Avineri, E.; Susilo, Y. Editorial JTH 16-The Coronavirus Disease COVID-19 and implications for transport and health. J. Transp. Health 2020, 16, 100853. [CrossRef] [PubMed]

11. Neuwirth, L.S.; Jović, S.; Mukherji, B.R. Reimagining higher education during and post-COVID-19: Challenges and opportunities. J. Adult Contin. Educ. 2020, 27, 141-156. [CrossRef]

12. Spennemann, D.H.R.; Whitsed, R. The impact of COVID-19 on the Australian outdoor recreation industry from the perspective of practitioners. J. Outdoor Recreat. Tour. 2021, in press. [CrossRef]

13. Haywood, K.M. A post-COVID future: Tourism community re-imagined and enabled. Tour. Geogr. 2020, 22, 599-609. [CrossRef]

14. Bereitschaft, B.; Scheller, D. How Might the COVID-19 Pandemic Affect 21st Century Urban Design, Planning, and Development? Urban Sci. 2020, 4, 56. [CrossRef]

15. Spennemann, D.H.R. Preparing for COVID-2x: Urban planning needs to regard urological wastewater as an invaluable communal public health asset and not as a burden. Urban Des. 2021, 5, 75. [CrossRef]

16. Honey-Rosés, J.; Anguelovski, I.; Chireh, V.K.; Daher, C.; Konijnendijk van den Bosch, C.; Litt, J.S.; Mawani, V.; McCall, M.K.; Orellana, A.; Oscilowicz, E. The impact of COVID-19 on public space: An early review of the emerging questions-design, perceptions and inequities. Cities Health 2020, 1-17. [CrossRef]

17. Moloney, K.; Moloney, S. Australian Quarantine Policy: From centralization to coordination with mid-Pandemic COVID-19 shifts. Public Adm. Rev. 2020, 80, 671-682. [CrossRef] [PubMed]

18. Chinazzi, M.; Davis, J.T.; Ajelli, M.; Gioannini, C.; Litvinova, M.; Merler, S.; Piontti, A.P.y.; Mu, K.; Rossi, L.; Sun, K. The effect of travel restrictions on the spread of the 2019 novel coronavirus (COVID-19) outbreak. Science 2020, 368, 395-400. [CrossRef] [PubMed]

19. Askitas, N.; Tatsiramos, K.; Verheyden, B. Lockdown strategies, mobility patterns and COVID-19. arXiv Preprint 2020, arXiv:2006.00531.

20. Shakespeare-Finch, J.; Bowen-Salter, H.; Cashin, M.; Badawi, A.; Wells, R.; Rosenbaum, S.; Steel, Z. COVID-19: An Australian Perspective. J. Loss Trauma 2020, 25, 662-672. [CrossRef]

21. Woskie, L.R.; Wenham, C. Do men and women lockdown differently? An examination of Panama's COVID-19 sex-segregated social distancing policy. medRxiv 2020. [CrossRef]

22. Kanbur, N.; Akgül, S. Quaranteenagers: A Single Country Pandemic Curfew Targeting Adolescents in Turkey. J. Adolesc. Health 2020, 67, 292. [CrossRef]

23. Spennemann, D.H.R. "No Entry into New South Wales": COVID-19 and the Historic and Contemporary Trajectories of the Effects of Border Closures on an Australian Cross-Border Community. Land 2021, 10, 610. [CrossRef] 
24. MHMR. Public Health (COVID-19 Restrictions on Gathering and Movement) Order 2020 (30 March 2020). New South Wales Gov. Gaz. 2020, 65, 1149-1163.

25. MHMR. Public Health (COVID-19 Greater Sydney) Order 2021. N. S. W. Gov. Gaz. 2021, 178, 1-8.

26. MHMR. Public Health (COVID-19 Greater Sydney) Order (No 2) 2021. N. S. W. Gov. Gaz. 2021, 266, 1-13.

27. MHMR. Public Health (COVID-19 Additional Restrictions for Delta Outbreak) Amendment (No 27) Order 2021. N. S. W. Gov. Gaz. 2021, 369, 1-6.

28. MHMR. Public Health (COVID-19 Temporary Movement and Gathering Restrictions) Order 2021. N. S. W. Gov. Gaz. 2021, 282, $1-17$.

29. Spennemann, D.H.R. COVID face masks: Policy shift results in increased littering. Sustainability 2021, 13, 9875. [CrossRef]

30. Spennemann, D.H.R. Facing COVID-19: Quantifying the use of reusable vs. disposable facemasks. Hygiene 2021, 1, 120-128. [CrossRef]

31. Mackenzie, S.H.; Goodnow, J. Adventure in the age of COVID-19: Embracing microadventures and locavism in a post-pandemic world. Leis. Sci. 2020, 43, 62-69. [CrossRef]

32. Rice, W.L.; Mateer, T.; Taff, B.D.; Lawhon, B.; Reigner, N.; Newman, P. Longitudinal changes in the outdoor recreation community's reaction to the COVID-19 pandemic: Final report on a three-phase national survey of outdoor enthusiasts. SocArXiv 2020. [CrossRef]

33. Rice, W.L.; Mateer, T.J.; Taff, B.D.; Lawhon, B.; Newman, P. Continued longitudinal analysis of avid outdoor recreationists during the COVID-19 pandemic and sensitivities to new outdoor recreationists. SocArXiv 2021. [CrossRef]

34. O'Connell, T.S.; Howard, R.A.; Hutson, G. The Impact of COVID-19 on Outdoor Recreation Participation in Canada; Brock University: St. Catharines, ON, Canada, 2020.

35. Douglas, M.; Katikireddi, S.V.; Taulbut, M.; McKee, M.; McCartney, G. Mitigating the wider health effects of covid-19 pandemic response. BMJ 2020, 369, m1557. [CrossRef]

36. Grant, R.; Gorman-Murray, A.; Briohny Walker, B. The Spatial Impacts of COVID-19 restrictions on LGBTIQ wellbeing, visibility, and belonging in Tasmania, Australia. J. Homosex. 2021, 68, 647-662. [CrossRef] [PubMed]

37. Bil, J.S.; Buława, B.; Świerzawski, J. Mental Health and the City in the Post-COVID-19 Era. Sustainability 2021, 13, 7533. [CrossRef]

38. Pouso, S.; Borja, Á.; Fleming, L.E.; Gómez-Baggethun, E.; White, M.P.; Uyarra, M.C. Contact with blue-green spaces during the COVID-19 pandemic lockdown beneficial for mental health. Sci. Total Environ. 2021, 756, 143984. [CrossRef] [PubMed]

39. Heo, S.; Desai, M.U.; Lowe, S.R.; Bell, M.L. Impact of Changed Use of Greenspace during COVID-19 Pandemic on Depression and Anxiety. Int. J. Environ. Res. Public Health 2021, 18, 5842. [CrossRef]

40. Ettman, C.K.; Abdalla, S.M.; Cohen, G.H.; Sampson, L.; Vivier, P.M.; Galea, S. Prevalence of Depression Symptoms in US Adults Before and During the COVID-19 Pandemic. JAMA Netw. Open 2020, 3, e2019686. [CrossRef] [PubMed]

41. Geary, R.S.; Wheeler, B.; Lovell, R.; Jepson, R.; Hunter, R.; Rodgers, S. A call to action: Improving urban green spaces to reduce health inequalities exacerbated by COVID-19. Prev. Med. 2021, 145, 106425. [CrossRef] [PubMed]

42. Alizadehtazi, B.; Tangtrakul, K.; Woerdeman, S.; Gussenhoven, A.; Mostafavi, N.; Montalto, F.A. Urban Park Usage During the COVID-19 Pandemic. J. Extrem. Events 2020, 7, 2150008. [CrossRef]

43. Uchiyama, Y.; Kohsaka, R. Access and use of green areas during the covid-19 pandemic: Green infrastructure management in the "new normal". Sustainability 2020, 12, 9842. [CrossRef]

44. Storen, R.; Corrigan, N. COVID-19: A chronology of state and territory government announcements (up until 30 June 2020). In Parliamentary Library Research Paper Series 2020-21; Parliamentary Library, Commonwealth of Australia: Canberra, Australia, 2020.

45. Fearnbach, S.N.; Flanagan, E.W.; Höchsmann, C.; Beyl, R.A.; Altazan, A.D.; Martin, C.K.; Redman, L.M. Factors Protecting against a Decline in Physical Activity during the COVID-19 Pandemic. Med. Sci. Sports Exerc. 2021, 53, 1391-1399. [CrossRef]

46. Cugusi, L.; Di Blasio, A.; Bergamin, M. The social media gym-class: Another lesson learnt from COVID-19 lockdown. Sport Sci. Health 2021, 17, 487-488. [CrossRef]

47. Meiring, R.M.; Gusso, S.; McCullough, E.; Bradnam, L. The effect of the COVID-19 pandemic movement restrictions on selfreported physical activity and health in New Zealand: A cross-sectional survey. Int. J. Environ. Res. Public Health 2021, 18, 1719. [CrossRef] [PubMed]

48. Nyenhuis, S.M.; Greiwe, J.; Zeiger, J.S.; Nanda, A.; Cooke, A. Exercise and fitness in the age of social distancing during the COVID-19 pandemic. J. Allergy Clin. Immunol. Pract. 2020, 8, 2152. [CrossRef]

49. Hartig, T.; Mitchell, R.; de Vries, S.; Frumkin, H. Nature and Health. Annu. Rev. Public Health 2014, 35, 207-228. [CrossRef]

50. van den Bosch, M.; Ode Sang, $\AA$. Urban natural environments as nature-based solutions for improved public health-A systematic review of reviews. Environ. Res. 2017, 158, 373-384. [CrossRef] [PubMed]

51. Triguero-Mas, M.; Dadvand, P.; Cirach, M.; Martínez, D.; Medina, A.; Mompart, A.; Basagaña, X.; Gražulevičienė, R.; Nieuwenhuijsen, M.J. Natural outdoor environments and mental and physical health: Relationships and mechanisms. Environ. Int. 2015, 77, 35-41. [CrossRef]

52. Taylor, M.S.; Wheeler, B.W.; White, M.P.; Economou, T.; Osborne, N.J. Research note: Urban street tree density and antidepressant prescription rates-A cross-sectional study in London, UK. Landsc. Urban Plan. 2015, 136, 174-179. [CrossRef]

53. Van Dillen, S.M.; de Vries, S.; Groenewegen, P.P.; Spreeuwenberg, P. Greenspace in urban neighbourhoods and residents' health: Adding quality to quantity. J. Epidemiol. Community Health 2012, 66, e8. [CrossRef] [PubMed] 
54. Lopez, B.; Kennedy, C.; McPhearson, T. Parks are Critical Urban Infrastructure: Perception and Use of Urban Green Spaces in NYC During COVID-19. Preprints 2020, 2020080620. [CrossRef]

55. Noël, C.; Rodriguez-Loureiro, L.; Vanroelen, C.; Gadeyne, S. Perceived health impact and usage of public green spaces in Brussels' metropolitan area during the COVID-19 epidemic. Front. Sustain. Cities 2021, 3, 30. [CrossRef]

56. Xie, J.; Luo, S.; Furuya, K.; Sun, D. Urban Parks as Green Buffers During the COVID-19 Pandemic. Sustainability 2020, $12,6751$. [CrossRef]

57. Venter, Z.S.; Barton, D.N.; Gundersen, V.; Figari, H.; Nowell, M.S. Back to nature: Norwegians sustain increased recreational use of urban green space months after the COVID-19 outbreak. Landsc. Urban Plan. 2021, 214, 104175. [CrossRef]

58. Geng, D.C.; Innes, J.; Wu, W.; Wang, G. Impacts of COVID-19 pandemic on urban park visitation: A global analysis. J. For. Res. 2021, 32, 553-567. [CrossRef]

59. Grima, N.; Corcoran, W.; Hill-James, C.; Langton, B.; Sommer, H.; Fisher, B. The importance of urban natural areas and urban ecosystem services during the COVID-19 pandemic. PLoS ONE 2020, 15, e0243344. [CrossRef] [PubMed]

60. Volenec, Z.M.; Abraham, J.O.; Becker, A.D.; Dobson, A.P. Public parks and the pandemic: How park usage has been affected by COVID-19 policies. PLoS ONE 2021, 16, e0251799. [CrossRef]

61. Ugolini, F.; Massetti, L.; Calaza-Martínez, P.; Cariñanos, P.; Dobbs, C.; Ostoić, S.K.; Marin, A.M.; Pearlmutter, D.; Saaroni, H.; Sauliene, I.; et al. Effects of the COVID-19 pandemic on the use and perceptions of urban green space: An international exploratory study. Urban For. Urban Green. 2020, 56, 126888. [CrossRef] [PubMed]

62. O'Brien, L.; Forster, J. Engagement with nature and Covid-19 restrictions. In Quantitative Analysis 2020; Research Agency of the Forestry Commission: London, UK, 2020.

63. Robinson, J.M.; Brindley, P.; Cameron, R.; MacCarthy, D.; Jorgensen, A. Nature's role in supporting health during the COVID-19 pandemic: A geospatial and socioecological study. Int. J. Environ. Res. Public Health 2021, 18, 2227. [CrossRef] [PubMed]

64. Lehberger, M.; Kleih, A.-K.; Sparke, K. Self-reported well-being and the importance of green spaces-A comparison of garden owners and non-garden owners in times of COVID-19. Landsc. Urban Plan. 2021, 212, 104108. [CrossRef]

65. Ugolini, F.; Massetti, L.; Pearlmutter, D.; Sanesi, G. Usage of urban green space and related feelings of deprivation during the COVID-19 lockdown: Lessons learned from an Italian case study. Land Use Policy 2021, 105, 105437. [CrossRef]

66. Larcher, F.; Pomatto, E.; Battisti, L.; Gullino, P.; Devecchi, M. Perceptions of Urban Green Areas during the Social Distancing Period for COVID-19 Containment in Italy. Horticulturae 2021, 7, 55. [CrossRef]

67. Fagerholm, N.; Eilola, S.; Arki, V. Outdoor recreation and nature's contribution to well-being in a pandemic situation-Case Turku, Finland. Urban For. Urban Green. 2021, 64, 127257. [CrossRef] [PubMed]

68. Dushkova, D.; Ignatieva, M.; Hughes, M.; Konstantinova, A.; Vasenev, V.; Dovletyarova, E. Human dimensions of urban blue and green infrastructure during a pandemic. Case study of Moscow (Russia) and Perth (Australia). Sustainability 2021, 13, 4148. [CrossRef]

69. Lu, Y.; Zhao, J.; Wu, X.; Lo, S.M. Escaping to nature during a pandemic: A natural experiment in Asian cities during the COVID-19 pandemic with big social media data. Sci. Total Environ. 2021, 777, 146092. [CrossRef]

70. Cheng, Y.; Zhang, J.; Wei, W.; Zhao, B. Effects of urban parks on residents' expressed happiness before and during the COVID-19 pandemic. Landsc. Urban Plan. 2021, 212, 104118. [CrossRef]

71. Soga, M.; Evans, M.J.; Tsuchiya, K.; Fukano, Y. A room with a green view: The importance of nearby nature for mental health during the COVID-19 pandemic. Ecol. Appl. 2021, 31, e2248. [CrossRef] [PubMed]

72. Huerta, C.M.; Utomo, A. Evaluating the association between urban green spaces and subjective well-being in Mexico city during the COVID-19 pandemic. Health Place 2021, 70, 102606. [CrossRef]

73. Scott, R.P. Shared streets, park closures and environmental justice during a pandemic emergency in Denver, Colorado. J. Transp. Health 2021, 21, 101075. [CrossRef]

74. Kleinschroth, F.; Kowarik, I. COVID-19 crisis demonstrates the urgent need for urban greenspaces. Front. Ecol. Environ. 2020, 18, 318. [CrossRef]

75. Sainz-Santamaria, J.; Martinez-Cruz, A.L. Governance of Urban Green Spaces Across Latin America-Insights from SemiStructured Interviews to Managers Amid COVID-19. 2021. Available online: https:/ / doi.org/10.2139/ssrn.3782285 (accessed on 1 September 2020).

76. Pan, J.; Bardhan, R.; Jin, Y. Spatial distributive effects of public green space and COVID-19 infection in London. Urban For. Urban Green. 2021, 62, 127182. [CrossRef]

77. WHO. Coronavirus Disease (COVID-19) Advice for the Public. Available online: https://www.who.int/emergencies/diseases/n ovel-coronavirus-2019/advice-for-public (accessed on 1 September 2020).

78. Qian, M.; Jiang, J. COVID-19 and social distancing. J. Public Health 2020, 1-3. [CrossRef]

79. Kim, E.A. Social Distancing and Public Health Guidelines at Workplaces in Korea: Responses to COVID-19. Saf. Health Work 2020, 11, 275-283. [CrossRef] [PubMed]

80. MHMR. Public Health (COVID-19 Gatherings) Order 2020 (20 March 2020). N. S. W. Gov. Gaz. 2020, 53, 1035-1045.

81. Sugiyama, T.; Francis, J.; Middleton, N.J.; Owen, N.; Giles-Corti, B. Associations Between Recreational Walking and Attractiveness, Size, and Proximity of Neighborhood Open Spaces. Am. J. Public Health 2010, 100, 1752-1757. [CrossRef]

82. Ekkel, E.D.; de Vries, S. Nearby green space and human health: Evaluating accessibility metrics. Landsc. Urban Plan. 2017, 157, 214-220. [CrossRef] 
83. Cohen, D.A.; Marsh, T.; Williamson, S.; Derose, K.P.; Martinez, H.; Setodji, C.; McKenzie, T.L. Parks and physical activity: Why are some parks used more than others? Prev. Med. 2010, 50, S9-S12. [CrossRef] [PubMed]

84. Dallimer, M.; Irvine, K.N.; Skinner, A.M.; Davies, Z.G.; Rouquette, J.R.; Maltby, L.L.; Warren, P.H.; Armsworth, P.R.; Gaston, K.J. Biodiversity and the feel-good factor: Understanding associations between self-reported human well-being and species richness. BioScience 2012, 62, 47-55. [CrossRef]

85. Carrus, G.; Scopelliti, M.; Lafortezza, R.; Colangelo, G.; Ferrini, F.; Salbitano, F.; Agrimi, M.; Portoghesi, L.; Semenzato, P.; Sanesi, G. Go greener, feel better? The positive effects of biodiversity on the well-being of individuals visiting urban and peri-urban green areas. Landsc. Urban Plan. 2015, 134, 221-228. [CrossRef]

86. Polat, Z. The Identity and Hierarchy of Urban Parks: Planning to design and Management. In Theory and Research in Sport Sciences; Karataş, Ö.R., Ed.; Gece Publishing: Ankara, Turkey, 2021; pp. 39-58.

87. Rigolon, A.; Németh, J. What shapes uneven access to urban amenities? Thick injustice and the legacy of racial discrimination in Denver's parks. J. Plan. Educ. Res. 2021, 41, 312-325. [CrossRef]

88. Santiago, L.E.; Ortiz, J.C.V.; Santiago-Bartolomei, R.; Melendez-Ackerman, E.J.; Garcia-Montiel, D.C. Uneven access and underuse of ecological amenities in urban parks of the Río Piedras watershed. Ecol. Soc. 2014, 19, 26. [CrossRef]

89. Wang, D.; Brown, G.; Zhong, G.; Liu, Y.; Mateo-Babiano, I. Factors influencing perceived access to urban parks: A comparative study of Brisbane (Australia) and Zhongshan (China). Habitat Int. 2015, 50, 335-346. [CrossRef]

90. Knight, A.; Black, R.; Whitsed, R.; Harvey, R. Enhancing the usability and benefits of open space for older people in regional Australia. Aust. Plan. 2018, 55, 73-83. [CrossRef]

91. Whitsed, R.; Black, R.; Harvey, R.; Knight, A.; Watkins, S.; Armstrong, D. Better parks for people. Australas. Parks Leis. 2016, 19, 38-39.

92. Parker, M.; Spennemann, D.H.R. Responses to government-imposed restrictions: The sound of Australia's church bells one year after the onset of COVID-19. J. Acoust. Soc. Am. 2021, 150, 2677-2681. [CrossRef]

93. Astell-Burt, T.; Feng, X. Time for 'green'during COVID-19? Inequities in green and blue space access, visitation and felt benefits. Int. J. Environ. Res. Public Health 2021, 18, 2757. [CrossRef]

94. Berdejo-Espinola, V.; Suárez-Castro, A.F.; Amano, T.; Fielding, K.S.; Oh, R.R.Y.; Fuller, R.A. Urban green space use during a time of stress: A case study during the COVID-19 pandemic in Brisbane, Australia. People Nat. 2021, 3, 597-609. [CrossRef] [PubMed]

95. Spennemann, D.H.R.; Parker, M. Hitting the 'Pause' Button: What does COVID tell us about the future of heritage sounds? Noise Mapp. 2020, 7, 265-275. [CrossRef]

96. Chakraborty, T.; Sarangi, C.; Lee, X. Reduction in human activity can enhance the urban heat island: Insights from the COVID-19 lockdown. Environ. Res. Lett. 2021, 16, 054060. [CrossRef]

97. O'Brien, L.; Forster, J. Physical Activity Supporting Connection to Nature, and Helping to Maintain Wellbeing during the Covid-19 Restrictions in England. Int. J. Environ. Res. Public Health 2021, 18, 4585. [CrossRef]

98. Foth, M.; Caldwell, G.A.; Fredericks, J. A COVID-19 Horizon Scan Looking for Post-Pandemic Implications for Design. In Proceedings of the Cumulus Roma 2021-Design Culture(s), Rome, Italy, 8-11 June 2021.

99. Stevens, N.J.; Tavares, S.G.; Salmon, P.M. The adaptive capacity of public space under COVID-19: Exploring urban design interventions through a sociotechnical systems approach. Hum. Factors Ergon. Manuf. Serv. Ind. 2021, 31, 333-348. [CrossRef] [PubMed]

100. Lyster, R.; Lipman, Z.; Franklin, N.; Wiffen, G.J.; Pearson, L. Environmental and Planning Law in New South Wales; Federation Press: Alexandria, Australia, 2016.

101. Spiller, M. Land management and planning legislation. Urban Infrastructure: Finance and Management; Wiley: Chichester, UK, 2012; pp. 121-148.

102. NSW Government. An Act to Institute a System of Environmental Planning and Assessment for the State of New South Wales; NSW Government: Sydney, Australia, 1979.

103. Cameron, J.M.; Spooner, P. Origins of Travelling Stock Routes. 2. Early development, management, and the growing embrace of the law (1830-70s). Rangel. J. 2010, 32, 341-351. [CrossRef]

104. Spooner, P.G. On squatters, settlers and early surveyors: Historical development of country road reserves in southern New South Wales. Aust. Geogr. 2005, 36, 55-73. [CrossRef]

105. Wilson, J.; Tierney, P.; Kim, M.; Zieff, S.G. Temporary Parks? Sunday Streets, Serving the Need for Urban Outdoor Recreation. J. Park Recreat. Adm. 2012, 30, 38-52.

106. Firth, C.L.; Baquero, B.; Berney, R.; Hoerster, K.D.; Mooney, S.J.; Winters, M. Not quite a block party: COVID-19 street reallocation programs in Seattle, WA and Vancouver, BC. SSM-Popul. Health 2021, 14, 100769. [CrossRef] [PubMed]

107. Fischer, J.; Winters, M. COVID-19 street reallocation in mid-sized Canadian cities: Socio-spatial equity patterns. Can. J. Public Health 2021, 112, 376-390. [CrossRef]

108. Herman, K.; Drozda, Ł. Green Infrastructure in the Time of Social Distancing: Urban Policy and the Tactical Pandemic Urbanism. Sustainability 2021, 13, 1632. [CrossRef]

109. Lubell, S. 14 clever COVID-19 design solutions from around the world. Los Angeles Times, 29 December 2020.

110. Kotynski, L.; Kotynska, A. Social Distancing Lawn Brings People Together. Available online: https:/ / consortiumforsustainableur banization.org/2021/02/social-distancing-lawn-brings-people-together/ (accessed on 15 November 2021). 
111. Yui, L. Landscape Measure. Animating the University Landscape to Promote Social Distancing; Roger Williams University: Bristol, RI, USA, 2021.

112. Jordan, A. Into The Light of a Dark Black Night. Available online: https:/ / andyjordan.medium.com/into-the-light-of-a-dark-bla ck-night-57aa7ec7542f (accessed on 1 September 2021).

113. Hobbs, R.J.; Higgs, E.S.; Hall, C.M. Defining novel ecosystems. In Novel Ecosystems: Intervening in the New Ecological World Order; John Wiley \& Sons: New York, NY, USA, 2013; pp. 58-60.

114. Higgs, E. Novel and designed ecosystems. Restor. Ecol. 2017, 25, 8-13. [CrossRef]

115. Spennemann, D.H.R. The contribution of the Canary Island date palm (Phoenix canariensis) to the winter diet of frugivores in novel ecosystems. Europ. J. Ecol. 2019, 5, 27-37. [CrossRef]

116. Spennemann, D.H.R. The role of Canary Island date palms in physical amenity provisioning for urban landscape settings. Horticulturae 2021, 7, 201. [CrossRef]

117. Li, L.; Du, Q.; Ren, F.; Ma, X. Assessing spatial accessibility to hierarchical urban parks by multi-types of travel distance in Shenzhen, China. Int. J. Environ. Res. Public Health 2019, 16, 1038. [CrossRef] [PubMed]

118. City of Dallas. Dallas Parks Masterplan; City of Dallas: Dallas, TX, USA, 2015.

119. Silva, S.J.; Nascimento, J.; Reis, W.; Silva, C.; Silva, P.; Mendes, R.; Mendonca, A.; Santos, B.; Magalhaes, J.; Kohl, A. Widespread Contamination of SARS-CoV-2 on Highly Touched Surfaces in Brazil During the Second Wave of the COVID-19 Pandemic. medRxiv 2021. [CrossRef]

120. Elliott, S.; Drummond, M.; Prichard, I.; Eime, R.; Drummond, C.; Mason, R. Understanding the impact of COVID-19 on youth sport in Australia and consequences for future participation and retention. BMC Public Health 2021, 21, 448. [CrossRef] [PubMed]

121. Blocken, B.; Malizia, F.; Van Druenen, T.; Marchal, T. Towards Aerodynamically Equivalent COVID19 $1.5 \mathrm{~m}$ Social Distancing for Walking and Running. 2020. Available online: http://www.urbanphysics.net/Social\%20Distancing\%20v20_White_Paper.pdf (accessed on 15 November 2021).

122. Stroom, M.; Eichholtz, P.; Kok, N. Avoiding Crowded Places During COVID-19: Simple Choice or Complex Strategic Decision? 2021. Available online: https:/ / ssrn.com/abstract=3822441 (accessed on 15 November 2021).

123. Chan, H.F.; Skali, A.; Savage, D.A.; Stadelmann, D.; Torgler, B. Risk attitudes and human mobility during the COVID-19 pandemic. Sci. Rep. 2020, 10, 19931. [CrossRef] [PubMed]

124. Brand, D.; Nicholson, H.; Allen, N. The Role of Placemaking as a Tool for Resilience: Case Studies from Post-Earthquake Christchurch, New Zealand. In Earthquakes-Impact, Community Vulnerability and Resilience; IntechOpen: London, UK, 2019.

125. Brand, D.; Nicholson, H. Public space and recovery: Learning from post-earthquake Christchurch. J. Urban Des. 2016, 21, 159-176. [CrossRef]

126. Rupprecht, C.D.; Byrne, J.A.; Lo, A.Y. Memories of vacant lots: How and why residents used informal urban green space as children and teenagers in Brisbane, Australia, and Sapporo, Japan. Child. Geogr. 2016, 14, 340-355. [CrossRef]

127. Thorpe, A. A Day for Turning Parking Spaces into Pop-Up Parks. 2016. Available online: https://theconversation.com/a-day-fo r-turning-parking-spaces-into-pop-up-parks-65164 (accessed on 15 November 2021).

128. Gartry, L. Pop-Up Parks Prove Popular in Perth as Councils Cater for Pedestrians over Cars. Available online: https://www.abc. net.au/news /2015-09-18/pop-up-parks-catch-on-in-perth/6788094 (accessed on 1 September 2021).

129. Douay, N.; Prevot, M. Park (ing) day: Label international d'un activisme édulcoré? Environ. Urbain/Urban Environ. 2014, 8, 14-33.

130. Coombs, G. Park (ing) day. Contexts 2012, 11, 64-65. [CrossRef]

131. Rana, R.; Tripathi, A.; Kumar, N.; Ganguly, N. A comprehensive overview on COVID-19: Future perspectives. Front. Cell. Infect. Microbiol. 2021, 11, 744903. [CrossRef]

132. Alexandar, S.; Ravisankar, M.; Kumar, R.S.; Jakkan, K. A Comprehensive Review on Covid-19 Delta variant. Int. J. Pharmacol. Clin. Res. 2021, 5, 83-85.

133. Owen, N.; Cerin, E.; Leslie, E.; Coffee, N.; Frank, L.D.; Bauman, A.E.; Hugo, G.; Saelens, B.E.; Sallis, J.F. Neighborhood walkability and the walking behavior of Australian adults. Am. J. Prev. Med. 2007, 33, 387-395. [CrossRef]

134. Sugiyama, T.; Leslie, E.; Giles-Corti, B.; Owen, N. Physical activity for recreation or exercise on neighbourhood streets: Associations with perceived environmental attributes. Health Place 2009, 15, 1058-1063. [CrossRef] [PubMed]

135. Paydar, M.; Kamani Fard, A. The Hierarchy of Walking Needs and the COVID-19 Pandemic. Int. J. Environ. Res. Public Health 2021, 18, 7461. [CrossRef]

136. AustRoads. Guide to Road Design Part 6A: Pedestrian and Cyclist Paths; AustRoads: Sydney, Australia, 2009.

137. ACT Government. Design Standards for Urban Infrastructure, 13 Pedestrian \& Cycle Facilities; ACT Government: Canberra, Australia, 2007.

138. Lake Macquarie City Council. Footpath Strategy 2013 to 2023; Lake Macquarie City Council: Speers Point, Australia, 2013.

139. Department of Planning. Planning and Designing for Pedestrians: Guidelines; Department of Planning: Perth, Australia, 2011.

140. New South Wales. State Environmental Planning Policy (Exempt and Complying Development Codes) 2008; Regulation 572 of 2008; New South Wales: Sydney, Australia, 2008.

141. AlburyCity. Engineering Guidelines. Available online: https://www.alburycity.nsw.gov.au/property/plan/planning-controls/ engineering-guidelines (accessed on 10 September 2021). 
142. Albury Shire Council. Albury Development Control Plan; Albury Shire Council: Albury, Australia, 2010.

143. Hiemstra, J.A.; Saaroni, H.; Amorim, J.H. The urban heat island: Thermal comfort and the role of urban greening. In The Urban Forest; Springer: Berlin, Germany, 2017; pp. 7-19.

144. Onishi, A.; Cao, X.; Ito, T.; Shi, F.; Imura, H. Evaluating the potential for urban heat-island mitigation by greening parking lots. Urban For. Urban Green. 2010, 9, 323-332. [CrossRef] 